\title{
Assessing the impact of low level laser therapy (LLLT) on biological systems: a review
}

\section{Mussttaf, RA}

http://hdl.handle.net/10026.1/13174

\subsection{0/09553002.2019.1524944 \\ International Journal of Radiation Biology \\ Taylor \& Francis}

All content in PEARL is protected by copyright law. Author manuscripts are made available in accordance with publisher policies. Please cite only the published version using the details provided on the item record or document. In the absence of an open licence (e.g. Creative Commons), permissions for further reuse of content should be sought from the publisher or author. 


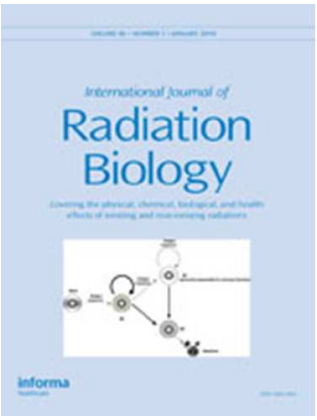

\section{Assessing the Impact of Low Level Laser Therapy (LLLT) on Biological Systems: A Review}

\begin{tabular}{|r|l|}
\hline Journal: & International Journal of Radiation Biology \\
\hline Manuscript ID & Draft \\
\hline Manuscript Type: & Review \\
\hline Date Submitted by the Author: & $\mathrm{n} / \mathrm{a}$ \\
\hline Keywords: List of Authors: & $\begin{array}{l}\text { Mussttaf, Ruwaidah ; University of Plymouth Faculty of Science and } \\
\text { Engineering, School of Computing, Electronics \& Mathematics } \\
\text { Jenkins, David; University of Plymouth Faculty of Science and Engineering, } \\
\text { School of Computing, Electronics \& Mathematics } \\
\text { Jha, Awadhesh; Plymouth University, Biological Sciences }\end{array}$ \\
\hline & $\begin{array}{l}\text { Low Level Laser Therapy (LLLT), cell proliferation, DNA damage, DNA } \\
\text { repair, Light Emitting Diodes (LEDs) }\end{array}$ \\
\hline
\end{tabular}




\title{
Assessing the Impact of Low Level Laser Therapy (LLLT) on Biological Systems: A Review
}

\author{
Ruwaidah A. Mussttaf ${ }^{1}$, David F. Jenkins ${ }^{1}$ and Awadhesh N. Jha ${ }^{2 *}$ \\ ${ }^{1}$ School of Computing, Electronics \& Mathematics, Plymouth University, PL4 8AA \\ ${ }^{2}$ School of Biological and Marine Sciences, University of Plymouth, PL4 8AA
}

*Correspondence: a.jha@plymouth.ac.uk

Running Title: Impact of LLLT on Biological Systems 
Abstract

Purpose: Low level Laser Therapy (LLLT) in the visible to near infrared spectral band (390 $-1100 \mathrm{~nm}$ ) is absorption of laser light at the electronic level, without generation of heat. It may be applied in a wide range of treatments including wound healing, inflammation and pain reduction. Despite its potential beneficial impacts, the use of lasers for therapeutic purposes still remains controversial in mainstream medicine. Whilst taking into account the physical characteristics of different qualities of lasers, this review aims to provide a comprehensive account of the current literature available in the field pertaining to their potential impact at cellular and molecular levels elucidating mechanistic interactions in different mammalian models. The review also aims to focus on the integral approach of the optimal characteristics of LLLT that suit a biological system target to produce the beneficial effect at the cellular and molecular levels.

Methods: Recent research papers were reviewed that explored the interaction of lasers (coherent sources) and LEDs (incoherent sources) at the molecular and cellular levels.

Results: It is envisaged that underlying mechanisms of beneficial impact of lasers to patients involves biological processes at the cellular and molecular levels. The biological impact or effects of LLLT at the cellular and molecular level could include cellular viability, proliferation rate, as well as DNA integrity and the repair of damaged DNA. This review summarises the available information in the literature pertaining to cellular and molecular effects of lasers.

Conclusions: It is suggested that a change in approach is required to understand how to exploit the potential therapeutic modality of lasers whilst minimising its possible detrimental effects. 
Key words: Low Level Laser Therapy (LLLT); cell proliferation; DNA damage; DNA repair, Light Emitting Diodes (LEDs); 


\section{Introduction}

Laser therapy or low-level laser therapy (LLLT) has been widely used for over 50 years [1]. Evolutionary, it emerged in its modern form after the invention of the laser in 1960 becoming a widespread treatment modality in a variety of clinical applications [2-4]. Investigators introduced a diverse set of terms to describe this potentially beneficial treatment tool [5]. Initially, expressions such as 'photobioactivation' and 'biostimulation' frequently relative to the stimulation effect of low level lasers were used $[6,7]$. Subsequently an inhibitory effect of this radiation were also noted, which led them to coin the term 'biomodulation' [8].

Recently a consensus decision was taken to use the terminology "photobiomodulation" or "PBM". Where some researchers gave LLLT a status of subjectivity, and it is limited for actual laser specific interactions, this is not a requirement for in-coherent light emitting diodes (LEDs) which can work equally well [9]. On the contrary, other researchers reported that although LLLT is a well-established researchable, and for much time used by clinician and researchers, but it is not optimal. It is a broad term that could include photodynamic therapy (PDT) and optogenetics, these techniques use lasers and LEDs with low dose and require exogenous chromophores, unlike LLLT that utilise endogenous chromophores with low dose of light delivered at the target site. However, they also suggest using photobiomodulation (PBM), since it is more ideal, has specific definition for this application of light to be more accurate and can confirm its scientific principle [10]. Specialists of medical field successfully used photobiomodulation in treating many health conditions when other methods had had limited success, such as healing-resistant wound, chronic diabetic ulcers, injuries of spinal cord and nervous system and pain management [11]. Nevertheless, photobiomodulation is not considered as a part of mainstream medicine as still not standard treatment [12]. 
LLLT treatment has evolved over the years and is being developed as a sophisticated tool for therapeutic procedures and utilized clinically for several different ailments [13]. The therapeutic treatments are based upon three principles; to minimize inflammation, edema, and chronic disorders of joints by targeting brain, skin, joint etc. [14], to promote wound healing of superficial and deeper tissues, neurological damage etc. $[4,15]$, and to treat neurological disorders and pain [13]. Recently, many studies on PBM therapy at infrared IR wavelengths, in particular from $700 \mathrm{~nm}$ up to the near infrared NIR [16-18], which was shown to produce more benefit impacts than red light in many medical conditions, including neural stimulation (by triggering direct activation of neural tissue) [19], photoaging (where IR radiation evidently has a biphasic effect), anti-tumor action (IR radiation is capable of inhibiting the proliferation of cancer cells and enhances chemotherapy efficacy, and brain neuroprotection (treatments for stroke, Traumatic brain injury (TBI) in vivo models [19, 20], and neurodegenerative disorders for Alzheimer's and Parkinson's diseases. These are given, in addition for many other diseases in Table1. Therefore, a better understanding of the mechanisms using IR radiation, could support improved therapeutic effectiveness via new strategies of PBM therapy at IR wavelengths [21].

Laser is a device which produces intense, monochromatic, coherent, and highly collimated beam of light [22]. Laser light has quite pure frequency, which makes it useful for biomedical applications [23]. Laser therapy involves visible red and near infrared (NIR) portions of the electromagnetic spectrum $\left(390-1600 \mathrm{~nm}\right.$ and $\left.10^{13}-10^{15} \mathrm{HZ}\right)$, because researchers have shown that these portions of the spectrum have been absorbed highly by the biological systems and bring about a beneficial therapeutic effects in living tissues [24]. According to the portion of the spectrum (wavelength) that strikes the tissue and the intensity (power density or irradiance) of laser radiation, the photobiological impacts of laser therapy on tissue are different that lead to divide the laser therapy into two classes [25]. Class I, which refers to 
radiation of wavelengths ranges $(<390 \mathrm{~nm})$ and $(>10,600 \mathrm{~nm})$ and high power and intensity levels, are used for ablation, cutting and sterilization, because of its thermal effect. Class II, which refers to radiation of wavelengths ranges $(390-10,600 \mathrm{~nm})$, levels of power $\left(10^{-3}\right.$ to $10^{-}$ $\left.{ }^{1} \mathrm{~W}\right)$ and intensity $\left(10^{-1}\right.$ to $\left.10^{0} \mathrm{~W} / \mathrm{cm}^{2}\right)$ and a dose of $10^{-2}$ to $10^{2} \mathrm{~J} / \mathrm{cm}^{2}$ [4].

Whereas there is some agreement on the best wavelengths of light and appropriate dosages to be used (irradiance and fluence), there is no agreement on the emission mode of laser light; whether continuous wave $(\mathrm{CW})$ or pulsed light is more suitable for the various applications of PBM. However, pulsed lasers in PBM therapy are used widely in clinical research $[22,26]$ and for medical treatment [27-30] Two types of pulsed laser are used for PBM therapy, a super-pulsing gallium-arsenide (GaAs) diode laser, which has a wavelength in the region of $904 \mathrm{~nm}$ and pulse duration in the range of 100-200 ns, and the semiconductor super-pulsing indium-gallium-arsenide (In-Ga-As) diode laser, which emits light at a similar wavelength (904-905 nm), producing very short pulses of light (200 ns) in the range of kilohertz $(\mathrm{kHz})$ frequencies [31]. Therapeutically, the super-pulsed GaAs and In-Ga-As lasers are capable of deep penetration without the undesirable influences associated with continues wave lasers (CW) (such as thermal damage), as well as allowing for shorter treatment periods. Pulsed lasers offer potential benefits, attributed to the pulse OFF times (pulse quench intervals) following the pulse $\mathrm{ON}$ times, so that pulsed lasers can deliver less tissue heating.

Low intensity laser radiation is clinically well accepted tool in medicine and dentistry [32]; Table 2]. It is featured by its ability to incite a thermic, non-damaging photobiological action [33]. Unlike hard high power laser, LLLT provides low energy only sufficient to induce stimulation response of body tissue, and has a wavelength-dependent manner able to change the cellular function. in the absence of considerable heating [34]. Hence, LLLT is also called soft laser therapy or cold laser, as low energy laser has no thermal effects $[13,35]$. 
Table1. Review of published studies using LLLT to treat different diseases.

It was observed that the broad range of laser therapy included molecular, cellular and tissue level effects and the modes of action of LLLT may vary with different confounding factors and applications [13]. To produce photo-biological action, photon absorption of laser radiation must occur [24]. Endogenous or exogenous chromophores are the initial photoacceptor molecules (i.e. molecules that can absorb light at certain wavelengths) absorb the incident photon energy [36]. A photochemical conversion of the photon energy absorbed by a photoacceptor has been demonstrated [37]. The absorbed energy of photon can be transferred to another molecule, which can then cause chemical reaction without alteration in temperature in the surrounding tissue $[37,38]$. Some native component can be activated in the irradiated cell at certain wavelength, and consequently, biochemical reaction as well as cellular metabolism might be altered [39].

Several studies suggested that mitochondria is the most sensitive component of cell to visible and near infrared light [39], [40], that result in increased production of adenosine triphosphate (ATP), increased deoxyribonucleic acid (DNA) synthesis, modulation of reactive oxygen species (ROS), nitric oxygen species (NOS) and the induction of transcription factors [41]. Moreover, PBM at red and NIR wavelengths stimulate increasing intracellular calcium $\mathrm{Ca}^{2+}[42-45]$, however recent studies emphasised that blue $(420 \mathrm{~nm})$ and green $(540 \mathrm{~nm})$ lights are more effective in increasing $\mathrm{Ca}^{2+}$ when applied at the same doses [46]. Many researchers suggested that the response of some cells to blue or green light interacting by light-gated ion channels, which enable light to control electrical excitability, intracellular acidity, calcium influx and other cellular processes [47-49]. The most likely ion channel is light-gated channel rhodopsin, because the action spectra of the channel rhodopsin family displays peaks in the blue-green spectral region [50]. The precise mechanism of laser- 
tissue interaction has not been completely explained, therefore there is no ability to offer a clinical treatment protocol at present [51].

The review of the available literature suggests that the variety of studies have been mostly in vitro, using a range of cell lines for different types of LLLT and varying some of their parameters, as summarised in Table 3. It is possible to select wavelength, power density, laser beam intensity profile, polarisation and exposure time. The available information suggests both positive and negative outcomes with respect to different parameters (Table 2).

It could be concluded that conflicting results have been published which may be attributed to a disparity in study design, including the use of different laser wavelengths, and numerous illumination parameters, in addition to different confounding factors which influence the determination of different biological parameters.

Table 2. Parameters involved in LLLT applications.

Table 3. Review of published studies evaluating the effects of LLLT on different cell lines.

\section{Optical Sources and Biological Interaction}

Low level laser irradiation has been used in clinical practice causing biostimulation. A number of diseases and physical conditions are mentioned to respond to laser therapy (photobiostimulation) [52]. At the cellular and molecular level, there is still significant argument regarding the effectiveness of lasers in producing the desired practical responses [52].

To illustrate the therapeutic effects, through optical stimulation processes, we introduce here briefly the available light sources and their potential to interact at the cellular and molecular level. Currently these are not well supported by the literature.

Laser light is generated on the principle of light amplification of stimulated emission of radiation [53]. The beam energy of laser light is powerful because it is highly coherent 
(waves are all in phase), polarized, focused and monochromatic (a single wavelength). It was first used in ophthalmological field in the early 1960s, although, the basic principle of laser was proposed by Einstein as back as in 1917 [53]. Lasers are commonly designated and named by the type of lasing material employed. The laser medium can be a solid state semiconductor, a gas, a liquid or a solid, as in Nd:YAG lasers which employ a Nd:YAG rod as the lasing medium [54] .

Laser light is characterised by its single wavelength, although some lasers, such as dye laser, can be tuned over a wide range of wavelengths [55]. Lasers are also classified according to their intensity and if they are pulsed or continuous wave $(\mathrm{CW})$, in order to identify the risk of harm to the patient [56]. In the medical field, lasers are classified as high power surgical lasers and low power therapeutic lasers [57]. Non-invasive or 'soft' lasers were introduced into medicine in the $1980 \mathrm{~s}$, and since then, have been seen as useful light sources for medical application [53]. The wavelengths of laser radiation used, have been investigated to show their therapeutic use [58].

LLLT or photobiomodulation, is a form of phototherapy, which is designed to apply low levels of red and near- infrared light with wavelengths in the region of 390-10600 nm and output powers up to $500 \mathrm{~mW}$ [59]. LLLT is effective in a number of clinical situations where the wavelength of red and near-infrared region are effective in such therapies. However, both of these two wavelength spectra are different in their photochemical and photophysical properties [58].

LLLT refers to the use of photon energy at low levels to alter biological activity with nothermal reactions because there is little increase in the temperature of the irradiated tissue [59]. Lasers of low level intensity are suggested to be non-toxic, non-allergic and because of their ease of application, these techniques have gained wide application in many fields of 
health care [53],Table1. Phototherapy has been found to have significant effects on a variety of pathological conditions including pain attenuation, inflammation and induction of wound healing in non-heating effects [59].

From observations, it appears that LLLT has beneficial effects at the molecular, cellular, and tissue levels [60]. It has been found that medical treatment with LLLT at various intensities has stimulatory effect on cellular processes [61]. Recently, it has been reported by several investigators that at low -levels of red or near-infrared light illumination, LLLT can prevent cell apoptosis $[59,62]$, stimulation of mitochondrial activity, increased cell turnover, recruitment and proliferation, modulation of the cellular metabolites [63]. It was suggested that LLLT might promote changes in the cellular redox state, playing an important role in sustaining cellular activities, and induce photobiostimlative processes [64]. In addition to the above, pre-exposure of PBM had a protective effect against many external agents such as hydrogen peroxide, $\mathrm{H}_{2} \mathrm{O}_{2}$, and $\mathrm{UV}$ radiation $[65,66]$. There is an evolutionary standpoint confirm that NIR pre-exposure protect cells from the hazard impacts of UV exposure, and the re-exposure for NIR radiation could be important for protection maintenance $[67,68]$

\section{Optical Properties of Tissues}

When the laser light strikes biological tissues, part of this light is absorbed, part is reflected or scattered, and the rest transmitted. Reflection phenomenon is produced due to a change in refractive index of air and tissue. Snell's law can be used to explain this phenomenon:

$$
\frac{\sin \theta_{1}}{\sin \theta_{2}}=\frac{n_{2}}{n_{1}} \quad \ldots \ldots \ldots
$$

Where $\theta_{1}$ is the angle between the incident light and the surface normal in the air, $\theta_{2}$ is the angle between the ray and the surface normal in the tissue, $n_{1,} n_{2}$ are the refractive index of air and tissue respectively [69]. 
Most of the light is absorbed by the tissue because the energy state of molecules is quantized; therefore, photonic absorption occurs only when its energy equals the energy difference between such quantized states. Absorption is key for the desired impact on tissue healing. The magnitude of optical absorption is described in terms of the absorption coefficient $\mu_{\mathrm{a}}$, in units of $\mathrm{cm}^{-1}[70]$. The depth of penetration (mean free path) into the absorbing medium is defined by the inverse, $I_{\mathrm{a}}[13]$.

The primary step for tissue interaction is scattering behaviour of light in the biological tissue, which is followed by absorption, it is also important because it determines the magnitude distribution of light intensity in the tissue. Scattering of a photon is synchronous with a change in the propagation direction without loss of energy. Analogous to absorption, scattering is expressed by the scattering coefficient $\mu_{\mathrm{s}}\left(\mathrm{cm}^{-1}\right)[69,71]$. The length until next scattering occurs is $1 / \mu_{\mathrm{s}}(\mathrm{cm})$. Scattering is not isotropic, having a physical property that has the same value when measured in different directions. Forward scattering prevail in biological tissue. This physical characteristic is expressed by the anisotropy factor giving absolute values for isotropic scattering $(g=0)$ to forward scattering $(g=1)$. In biological tissue, $g$ can differ from 0.8 to 0.99 , and can have a considerable role in a reduced scattering coefficient, $\mu_{s}{ }^{\prime}\left(\mathrm{cm}^{-1}\right)$, which can be defined as:

$$
\mu_{s}{ }^{\prime}=\mu_{\mathrm{s}}(1-g) \ldots(2)
$$

The sum of absorption coefficient $\left(\mu_{\mathrm{a}}\right)$ and scattering coefficient $\left(\mu_{\mathrm{s}}\right)$ is called the total attenuation coefficient, that the beam is "attenuated" (weakened) as it passes through the medium. Attenuation coefficient of the volume of a material characterizes how easily it can be penetrated by a beam of light, in other words, the fraction of an incident beam of photons that is absorbed or scattered per unit thickness of the target absorber, $\mu_{\mathrm{t}}\left(\mathrm{cm}^{-1}\right)$ : 


$$
\mu_{\mathrm{t}}=\mu_{\mathrm{s}}+\mu_{\mathrm{a}} \ldots \ldots(3)
$$

\subsection{Light Distribution in Laser-Irradiated Tissue}

Most of the recent evolutions in describing the transfer of light energy in tissue are based on transport theory [72] (radiative transfer), the physical phenomenon of energy transfer in the form of electromagnetic radiation. The propagation of radiation through a medium is affected by absorption, emission, and scattering processes $[72,73]$. According to transport theory, the radiance $L(r, s)$ of light at position $\mathrm{r}$ traveling in the direction of unit vector $\mathrm{s}$ is reduced by absorption and scattering, but it is increased by light that is scattered from $\mathrm{s}^{\prime}$ direction into direction s. Radiance is a radiometric measure that refers to the amount of light that passes through or is emitted from a particular area, and drops within a given solid angle in a particular direction. Then, the transport equation which describes the light interaction is:

$$
s . \nabla L(r, s)=-\left(\mu_{\mathrm{a}}+\mu_{\mathrm{s}}\right) L(r, s)+\mu_{\mathrm{s}} \int_{4 \pi}^{p\left(s, s^{\prime}\right) L\left(r, s^{\prime}\right) d \omega^{\prime} \ldots . .}
$$

Where $d \omega^{\prime}$ is the differential solid angle in the direction $s^{\prime}$, and $p\left(s, s^{\prime}\right)$ is the phase function $[13,74]$.

Determining the distribution of light in an irradiated tissue is based on the transport equation requiring $\mu_{\mathrm{s}}, \mu_{\mathrm{a}}$ and $p$. An exact solution for transport equation is often difficult, therefore several approximations have been made concerning the illustration of the radiance and phase function. The approximate calculations of distributed light in tissue are related to the type of light irradiation (diffuse or collimated) and the optical boundary conditions (matched or unmatched refractive indexes) [74]. 


\section{The Mechanism of Laser-Sub-cellular and Cellular Interaction}

It is being suggested that the key underlying mechanism of action for most of the physiological effects attributed to LLLT is the stimulation of mitochondrial activity [63], [75]. The first law of photobiology states that photons of low power light must be absorbed by electronic absorption bands belonging to chromophores to produce significant effects on living biological systems [62]. A chromophore (or photoacceptor) is a molecule of a compound, which imparts some colour to the compound [76].

According to the theory of quantum mechanics by Max Planck (1900), light energy consists of photons or discrete packets of electromagnetic energy. The individual photon energy depends on the wavelength; therefore, the dose energy of light depends on the number of photons, their wavelength and surface area through spot-size of the laser [41].

When photons from a laser are incident on living tissue, it can be locally absorbed or could scatter. Scattered photons are reflected or transmitted [41]. Absorbed photons interact with the chromophore molecule located within the tissue. The absorption of light leads to excitation of electrons to higher energy levels. The delocalized electrons of the energized molecule which are excited rise from the ground state to an excited state [77]. This excited molecule must lose its extra energy, which must be conserved according to the first law of thermodynamics. Three possible pathways occur when LLLT is delivered into tissue.

Pathway 1: The commonest pathway that occurs is called internal conversion, the excited singlet state of chromophore transport from a higher to a lower electronic state. This transition takes place without photons emitting, known as non-radiative decay [41]. The energy of the electronically excited state is coupled to rotational and vibrational modes of the molecule. Thus, this interaction increases the kinetic energy of the molecule, such that the 
excitation energy is transformed into heat. This process would not be expected to cause chemical changes to the molecule [58].

Pathway 2: The second pathway that can occur is fluorescence. Fluorescence is re-emission of light by a substance that has absorbed light. It is a form of luminescence. The excited molecule tends to return to its stable state by emitting photons with a longer wavelength (i.e., lower energy than the absorbed photon) [77]. The resultant heat (from molecular vibrations) arises from the energy difference between the absorbed and emitted photons.

Pathway 3: The third pathway that can occur after the absorption of low level laser light by a tissue photo-acceptor representing a number of photochemical processes. Although, covalent bonds cannot be broken by low energy photons, the energy is however sufficient for electrons to go from the first excited singlet state to the triplet state of the photoacceptor through intersystem crossing. Increasing the reaction rate allows transforming such as ground state molecular oxygen (a triplet) to singlet oxygen state (reactive oxygen species). Alternatively, the long-lived triplet of the chromophore may undergo electron transfer to form a radical anion, which can transfer an electron to oxygen to form a superoxide [41].

The photochemical pathway is the separation of a non-covalent bound ligand from a binding site on a metal in an enzyme. Cytochrome c oxidase, the terminal enzyme of the mitochondrial respiratory chain in eukaryotic cells is the candidate enzyme for a photoacceptor (chromophore), a molecule imparts a color to a compound, mediating the transfer of electrons from cytochrome $\mathrm{c}$ to molecular oxygen. After absorbing red or nearinfrared light, cytochrome c oxidase undergoes photochemical processes through the dissociation of binding of nitric oxide from the iron-containing and copper-containing redox centres in the enzyme [41]. There is a growing body of evidence which suggests that cytochrome c oxidase could act as a photoacceptor of light in the near-infrared spectral range 
[64]. It is also considered as the photosignal transducer in the region of visible and IR-A region [78]. This reactivity is due to four redox active metal centers: the bi-nuclear $\mathrm{CuA}, \mathrm{CuB}$, heme a, and heme a3, all of which have strong absorbency in the red to IR-A range [78-80].

Many studies on the biological influence of LLLT have compared the action spectrum, a plot of the relative effectiveness of different wavelengths of light in causing a particular biological response, and under ideal conditions it should follow the absorption spectrum of the specific molecule, and whose photochemical alteration causes the biological effect attributed to the absorption spectra. These studies have suggested cytochrome c oxidase as the primary photoacceptor (chromophores) [77, 81].

Cytochrome c oxidase is the fourth enzyme in the inner membrane of cellular mitochondria $[63,82]$, as shown in (Figure 1), that plays a pivotal role in Adenosine tri phosphate (ATP) synthesis [64]. Excitation of cytochrome c oxidase components with infrared light energy accelerates the rate of electron transfer and in turn increases the ability of mitochondria to produce ATP, which accelerates cellular metabolic processes [64]. Moreover, signal transduction to other parts of the cell has occurred, including cell membranes [83]. Photobiological responses are the result of photochemical and /or photophysical changes after the absorption of non-ionizing electromagnetic radiation [58].

Figure 1 The mitochondrial respiratory chain. (Figure adapted from [76]).

Production of nitric oxide (NO) in mitochondria especially in injured or hypoxic cells can inhibit respiration by binding to cytochrome c oxidase and displace oxygen [84]. This binding is proposed to dissociate by the PBM or LLLT effect, and reverse the mitochondrial inhibition of respiration due to excessive NO binding [85]. The photobiomodulation effect of LLLT is able to occur a shift in the overall cell redox potential in the direction of greater oxidation by generating reactive oxygen species (ROS) and inhibiting reactive nitrogen 
species (RNS) [86-90]. The excited mitochondrial cytochrome c oxidase after absorbing NIR radiation photon generates ROS that causes changing the oxidation state of the mitochondrial membrane [91].

For the phototherapeutic effect to be observed, the appropriate wavelength of light and dose (fluency) of radiation are needed [83]. However, phototherapy will not be effective on every system and in every situation. Karu (1989) [2] has emphasised that the magnitude of the phototherapy effect depends on the physiological state of the cell at the moment of irradiation $[2]$.

\section{Light Emitting Diodes (LEDs)}

A light emitting diode (LED) is a semiconductor light source [92]. Henry J Round was the first who reported of light emission from carborundum (raw silicon carbide) in 1907. Oleg Losev, as a lot of people today believe, was the actual inventor of LED. He published his first paper in 1927 on emission of silicon carbide diodes. Losev set up the current threshold for the onset of light emission from the contact point between a silicon carbide crystal and a metal wire and recorded the spectrum of this light $[81,93]$. A LED is formed by p-n junctions (ppositive, n-negative), but not all semiconductors are suitable for use as LEDs [94]. The physical mechanism by which LED emits light is spontaneous emission [94]. They emit near-monochromatic, incoherent light [95], in a process called electroluminescence [96]. LEDs are small, robust devices that emit a narrow band of electromagnetic radiation from the ultraviolet to the visible and infrared parts of the spectrum, from around $240 \mathrm{~nm}$ up to around $950 \mathrm{~nm}$, according to their electronic structure [95], with a linewidth of around 10-30 nm. LEDs have been publicised as a comfortable, potentially highly selective light-based therapies for many indications [97]. LEDs are also very controllable as light sources for nonthermal applications, acquiring a broad area of in medical applications [61]. 


\subsection{Laser Light vs Light Emitting Diode (LED)}

Not all light is the same or has equal medical benefits (LED or LASER therapy). Recently, controversy has arisen around the comparison between low level laser therapy and light emitting diodes, which have completely different biological effects [98]. A number of studies compared the effectiveness of LLLT to LED light (Figure 2), and the majority found, although lasers have small focused spots so only a small area of tissue $\left(<1 \mathrm{~cm}^{2}\right)$ is exposed to light; on the hand LEDs usually have a large area $\left(100 \mathrm{~cm}^{2}\right)$ so much more tissue is exposed to light however, lasers are far more effective [98]. Laser therapy can achieve much greater and deeper stimulative and therapeutically beneficial effects. Laser beams are easily manipulated using Gaussian beam optics, a simple analytical tool, to enable a laser beam to be fully controlled spatially, position, size etc. While an LED is difficult to control in terms of position and spot size, and so it is limited for treatment of superficial tissue only. However, LED light has some beneficial effect where it is believed that LED light can have a photomodulation effect on certain cellular and sub-cellular receptors. In addition, they have greater choice of wavelengths, are low cost and suitable for acute and chronic conditions [99].

Figure 2. Coherent sources and non-coherent (LED) of LLLT in clinical and laboratory studies on the effect of LLLT on cell and DNA from 1965-2018

A number of studies have been published comparing these two modalities. Kubota and Ohshiro [100] treated rat skin flaps with an $830 \mathrm{~nm}$ GaAlAs laser and an $840 \mathrm{~nm}$ infrared LED. They found an increasing flap survival area in a rat model after being irradiated with $830 \mathrm{~nm}$ laser. Flaps treated with the laser had better perfusion, a greater number of larger blood vessels, and significantly enhanced flow rates. While, flaps treated with an $840 \mathrm{~nm}$ IR LED showed no difference from the control group [100]. Berki et al. [101] used a HeNe laser to stimulate cell activation in vitro. They observed increasing phagocytic activity along 
with immunoglobulin secretion, but this effect was not seen after irradiation of the cell cultures with LED light of the same wavelength and doses [101].

A comparative study has been performed by Haina et al. [102] to show the effectiveness of $\mathrm{HeNe}$, coherent laser compared with incoherent light of the same wavelength. Experimental wounds were 'punched out' in the muscle fascia of 249 Wister rats. They reported increasing granulation of tissue in the $\mathrm{HeNe}$ treated group, whereas there was less granulation in the incoherent light therapy group [102].

Rockhind and colleagues [103] conducted a study comparing five different wavelengths lasers. They gave a single transcutaneous irradiation dose to injured peripheral nerves. They observed reduced subsidence in functional activity following crush injury after HeNe laser irradiation. While the $830 \mathrm{~nm}$ IR laser was less effective, the $660 \mathrm{~nm}$ incoherent light was even less effective; $880 \mathrm{~nm}$ and $950 \mathrm{~nm}$ incoherent lights were completely ineffective [103]. Laasko et al. [104] treated patients with chronic pain using an $820 \mathrm{~nm}$ IR laser at $25 \mathrm{~mW}$, a $670 \mathrm{~nm}$ laser at $10 \mathrm{~mW}$ and a $660 \mathrm{~nm}$ LED. They found an elevated level of ACTH and beta endorphin in the laser therapy groups but not in the LED group [104].

The effect of HeNe laser and incoherent LED light on leukocytes in migration inhibition assays has been studied by Lederer et al. [105]. They reported that irradiation with HeNe laser light affected leukocytes. While, incoherent light of the same wavelength and power density showed no influence [105]. Al. et al. [106] investigated the role of coherent laser therapy in wound healing. They noticed that HeNe lasers with a dose of $1 \mathrm{~J} / \mathrm{cm}^{2}$ produced an acceleration of the healing process, but incoherent light of the same wavelength and dose was less favourable [106].

Other studies have indicated many reasons which could lead to a preponderance of LED light than to laser light. NASA has stepped into developing LED light therapies for accelerating wound healing, photodynamic cancer treatment and much more. According to NASA: "The 
near-infrared light emitted by these LEDs seems to be perfect for increasing energy inside cells. This means whether you're on Earth, in a hospital, working in a submarine under the sea or on your way to Mars inside a spaceship, the LEDs boost energy to the cells and accelerate healing”[99, 107]. Oliveira and colleagues [108] studied the effect of low level light therapy on the healing of cutaneous wound and their impact on fibroblastic activity during wound healing. They showed an increasing number of healthy animals after irradiation with laser light, and a higher increase was seen when irradiated with LED. They concluded that using LED light caused a considerable bio-modulation of fibroblastic proliferation on anaemic animals. While laser light was more effective on increasing proliferation on non-anaemics [108]. A clinical study by Esper and colleagues [109] was carried out to show the effect of two phototherapy protocols on pain control in orthodontic procedure. They found that LED light therapy had a significant effect in the reduction of pain levels compared to laser light therapy. LED therapy showed a significant reduction in pain sensitivity (an average of 56\%), when compared to the control group [109].

Dall et al. [110] performed a comparative analysis of coherent laser light versus incoherent (light emitting diode) light for tissue repair in diabetic rats. They found that the coherent and incoherent lights produced similar effects during a period of $168 \mathrm{~h}$ after the lesions had been made. For the control group composed of diabetic animals, $72 \mathrm{~h}$ after creation of the lesion, it was observed that the therapy with LEDs had been more efficient compared with the laser for the reduction of the healing period [110]. Similar findings have been obtained by Klebanove and colleagues [111] in a comparative study of the effect of laser and light emitting diode irradiation on healing and functional activity of wound exudate leukocytes [111]. They deduced that coherent laser and incoherent light-emitting diode radiation have very similar effects on wound healing and activity of wound exudate leukocytes, and that the coherence of light is not required for this activity [111]. Another study by Klebanove and colleagues [112] 
has been carried out to explore the comparative effects of laser light and light emitting diodes on the production of superoxide dismutase and nitric oxide in wound fluid of rats. The study indicated that dose-dependent changes in superoxide dismutase activity and production of nitrites in wound fluid after irradiation with visible coherent laser and incoherent LED and the radiation coherence does not play any significant role in the changes of superoxide dismutase activity or nitrogen oxide formation [112].

The rapid evolution of light emitting diodes makes feasible the use of LEDs for medical treatment and light therapy [113]. The single frequency laser does not diffuse, whereas the LED light does. This diffusion allows the cell to be in control of the treatment [114]. Moreover, LED light therapy has been considered non-significant risk by the FDA [81]. For this reason it was published that using light emitting diodes for treatment is much safer than laser therapy [114].

Given the above information, and from recently published studies $[115,116]$, it has been shown that lasers have an important role in many medical conditions with many positive research results $[90,117,118]$, as well as LEDs which are also important in many cases of disease $[119,120]$. Nevertheless, in most comparative studies that used laser and LED with the same qualities (wavelength, doses, intensity), it is confirmed that LASERs offer many advantages compared to LEDs [121].

\section{Effects of LLLT at Cellular Level}

To assess the influence of low level laser therapy at the cellular level, cell cultures are one of the best biological systems used to find out the effect of laser irradiation on cell proliferation rate. Various studies, which have used different types of laser therapy with a variety of cells, have been designed to improve understanding on the effect of LLLT at the cellular level 
(Figure 3). More recent studies have studied the bio-stimulatory effect of low level laser on cell proliferation processes.

Early work by Karu and colleagues [122] have reported that the cytotoxic response of Hela cells to ionizing radiation can be influenced by irradiation with He-Ne laser $632.8 \mathrm{~nm}$ with an energy density $100 \mathrm{~J} / \mathrm{m}^{2}$. They observed that there was a substantial difference between the survival curve of Hela cells treated with He-Ne laser for $60 \mathrm{~min}$ before exposure to $\gamma_{-}$ irradiation and the curve representing the survival of untreated $\gamma$-irradiated cells. Moreover, an increase in the number of cells has been observed after stimulation with a He-Ne laser compared to the control group [122].

Pereira and colleagues [123] examined a $632.8 \mathrm{~nm}$ He-Ne laser with an energy fluence of 0.053 to $1.89 \mathrm{~J} / \mathrm{cm}^{2}$ and a $904 \mathrm{~nm}$ (GaAs) laser with an energy fluence of $1.94 \times 10^{-7}$ to $5.84 \times 10^{-6} \mathrm{~J} / \mathrm{cm}^{2}$ on fibroblast cell cultures, which determined by using the Trypan blue dye exclusion assay. No difference in cellular proliferation for fibroblast cells exposed to a He-Ne laser versus untreated fibroblast cells could be found. On the other hand, with GaAs laser, a decrease in cellular proliferation of fibroblast cells compared to controls was observed. However, both He-Ne and GaAs lasers induced procollagen production [123].

It was noted that with exposure to a $670 \mathrm{~nm}$ GaAlAs laser, an increase in myofibroblasts and collagen deposition was observed [124]. Furthermore, an increase in gingival fibroblasts after exposure to diode lasers $(670,692,780$, and $786 \mathrm{~nm})$ was also found [4].

Bouma and colleagues [125] examined human monocytes and human umbilical vein endothelial cells (HUVECs) with a $904 \mathrm{~nm}$ GaAs laser at $40.18 \mathrm{~mW} / \mathrm{cm}^{2}$ power density. They found no difference in the cytokines level such as tumour necrosis factor TNFa, interlukin-6 and -8, E-selectin, intercellular adhesion molecule 1, and vascular cellular adhesion molecule 1 [125]. Schindl and colleagues [126] reported that HUVECs irradiated 
with a $670 \mathrm{~nm}$ diode laser with a dose of 2 to $8 \mathrm{~J} / \mathrm{cm}^{2}$ resulted an increase in the proliferation of these cells, that determined by using a haemocytometer [126]. An in vitro study by Hass and colleagues [127] showed an increase in human keratinocytes mortality, that observed by inverted phase microscopy after exposure to He-Ne laser and found no change in proliferation or differentiation [127]. While, Grossman and colleagues [128] observed an increase in proliferation rate of keratinocyte cells, which counted microscopically using a counting chamber after exposure to a $780 \mathrm{~nm}$ continuous-wave diode laser with a dose from 0 to $3.6 \mathrm{~J} / \mathrm{cm}^{2}[128]$.

Figure 3. Light sources used in clinical and laboratory studies on the effect of LLLT on cell functions from 1965-2018.

Researchers pointed out that using low laser therapy with low doses can increase the proliferation rate of cultured cells when compared to high doses. Beyond a certain dose level, which is cell type dependent, high dose levels have a detrimental effect on cell proliferation rates. AlGhamdi and colleagues [59] have examined stem cells with a He-Ne laser at 632.8 $\mathrm{nm}$ and a GaAlAs at $600 \mathrm{~nm}$, with a range of energy densities (doses) from $0.5-4.0 \mathrm{~J} / \mathrm{cm}^{2}$ and power densities from 1-500 $\mathrm{mW}$ and found that LLLT can increase the proliferation rate of various cell lines. They have confirmed that the stimulation of cellular proliferation is dependent on the dose level of laser irradiation. They concluded that lower doses increase the rate of cell proliferation and other cellular functions, the determination of cell count and was achieved by using Trypan blue stain. Whereas, higher doses of low level laser therapy have negative effects, where the high doses caused a significant decrease in cells count and the percentage of cell viability [59]. Similar results have been obtained by Walsh and colleagues [129], when they irradiated fibroblasts of skin cells, buccal mucosa and gingival cells with semiconductor lasers at $540 \mathrm{~nm}$ and 600-900 nm and energy densities $0-56 \mathrm{~J} / \mathrm{cm}^{2}$. Walsh noted increased cell proliferation at low doses, which measured by using Trypan blue dye 
exclusion assay, and repressed at high doses. They, also observed increase maturation and locomotion, transformation to myo-fibroblasts, and increased production of basic fibroblasts growth factors

Walsh and colleagues [129] used the same laser with the same energy densities to examine macrophage cells. They observed convergent results, greater secretion of basic fibroblasts growth factors, increased ability to act as phagocytes, and resorption of fibrin by macrophages. Walsh in another study used semiconductor lasers of 660,820 , and $940 \mathrm{~nm}$ to treat human lymphocytes cells. They showed activated lymphocytes and high proliferation rate. With the same wavelengths, Walsh noted the increased motility of epithelial cells and an ability to migrate across wound sites with quickened closure of defects.

Unlike AlGhamdi and Walsh, Petri and colleagues [130] found that cell growth, as measured by MTT assay, was affected by time with LLLT after exposing human alveolar bone fragment cells to a GaAlAs diode laser of $780 \mathrm{~nm}$ with power of $70 \mathrm{~mW}$ and energy density 3 $\mathrm{J} / \mathrm{cm}^{2}$ [130]. Recently, Forouzanfar [131] has support Petri's results when examining human gingival fibroblasts with a Ga-Al-As diode laser at $810 \mathrm{~nm}$, output power $50 \mathrm{~mW}$ and energy density $4 \mathrm{~J} / \mathrm{cm}^{2}$. Forouzanfar noted that both good levels of cell proliferation and secretion of macromolecules can be regulated if enough exposure time of low level laser therapy has been given to the cells to determine whether LLLT could induce a bio-stimulatory effect on human cells. As well, they have found a significant difference between the case and control groups on 48 and $72 \mathrm{hr}$ after irradiation [131].

Tuby and colleagues [132] obtained a positive result when they exposed mesenchymal stem cells (MSCs) and cardiac stem cells (CSCs) to a GaAs diode laser at $804 \mathrm{~nm}$ with an energy density between 1 and $3 \mathrm{~J} / \mathrm{cm}^{2}$ and an output power $50 \mathrm{~mW}$. The results showed a significant increase of seven-fold and two-fold in the number of CSCs after 1 and 2 weeks post 
irradiation of $1 \mathrm{~J} / \mathrm{cm}^{2}$ for $20 \mathrm{sec}$ exposure and increased the number of MSCs and CSCs after 1 week post irradiation of $3 \mathrm{~J} / \mathrm{cm}^{2}$ compared to the control [132].

Almeida and colleagues [133] used diode laser with 670, 692, 780, and $786 \mathrm{~nm}$ wavelengths and fluence (energy density) of $2 \mathrm{~J} / \mathrm{cm}^{2}$ to show the comparison of LLLT effects on the proliferation rate of cultured human gingival fibroblast cells. They found that in the same fluence and with different output powers, infrared lasers induced a higher proliferation rate of cells compared to visible laser. Whilst lasers of equal output power were shown to have similar effect on cell growth independently of their wavelengths[133].

\section{Effect of LLLT at Molecular Level}

LLLT has been in existence for more than four decades. It has been found beneficial in a wide variety of therapeutic applications [57]. However, the possibility of induced DNA damage has now arisen; even though, this damage could be repairable [57]. Although, phototherapy is used in the biomedical treatment of many diseases, the mechanisms of lasermolecule interaction remain unclear and the deleterious effects of laser irradiation are still controversial [134].

LLLT is usually performed with visible red or near infrared laser light and with typical accumulated doses. Since employing wavelengths within the red side of the optical spectrum, which is likely to be less damaging to DNA than sun light, it is assumed that the doses per area of LLLT are safe when corresponding to the DNA damaging effects of a few minutes sunlight [134]. If such irradiation induces DNA breaks, these breaks are likely to be repaired immediately; otherwise unrepaired damage could lead to mutations consequently leading to development of cancer in the long run [135].

Different studies in eukaryotic and prokaryotic cells have reported adverse effects on cells and DNA damage after exposure to low power laser therapy [136] (Figure 4). Experimental 
data about the effect of these light sources with different power, wavelengths, and emission modes on DNA are however scared [78]. A study by Zhang and colleagues [137] using microarray technologies indicated that low intensity laser exposure (red light) at therapeutic doses has been demonstrated to promote expression of DNA repair genes following DNA lesions induced by free radicals [137].

Figure 4 Light sources for LLLT used in clinical and laboratory studies on the effect of LLLT on DNA from 1980-2018.

It has been reported that the photo-reactivating enzyme (DNA photolyase) distinguishes one type of DNA damage as its substrate (i.e. the cyclobutane-type pyrimidine dimer), and combines with these dimers in the dark [58]. However, when exposing the enzyme-substrate complex to visible light, the enzyme uses the absorbed energy of light to split the dimer to produce repaired DNA. Mbene [57] treated wounded human skin fibroblast cells by He-Ne laser with $5 \mathrm{~J} / \mathrm{cm}^{2}$ and $16 \mathrm{~J} / \mathrm{cm}^{2}$ doses. Irradiation with $5 \mathrm{~J} / \mathrm{cm}^{2}$ and $16 \mathrm{~J} / \mathrm{cm}^{2}$ showed insignificant change in DNA damage, as determined by alkaline comet assay, at $1 \mathrm{~h}$ when compared to their respective controls. However, a significant decrease in DNA damage at 24h incubation due to the mechanism of DNA damage repair was shown [57].

Fonseca and colleagues [22] irradiated E.coli cells with low intensity (AlGaInP) red laser with a power of $10 \mathrm{~mW}$ and with different fluencies $\left(1,4\right.$ and $\left.8 \mathrm{~J} / \mathrm{cm}^{2}\right)$. It was suggested that low-level red laser light induces DNA lesions as a result of the generation of free radicals. They suggested that biological effects induced by low level laser fluence could occur due to the generation of free radicals. They suggested that considerable importance should be given to low-level lasers for their potential to induce DNA repair and changes in gene expression profile of the irradiated cells [22]. 
A study by da Silva and colleagues [138] used an AlGaInP laser with a power output of 10 $\mathrm{mW}$, and with continuous or pulsed mode of irradiation. They found that low-intensity red laser radiation could induce DNA lesions via oxidative mechanisms. Moreover it was found that the survival mechanism against harmful radiation could be activated or induced after irradiation with monochromatic red light [138]. Kohli and colleagues [139] examined E.coli cells with a He-Ne laser at $632.8 \mathrm{~nm}$. They observed that irradiation with low level He-Ne lasers induces photolyase gene $(p h r)$ and DNA repair genes investigated by phr gene expression assay. The magnitude of induction relies on fluence rate of the He-Ne laser and the time of incubation post irradiation. The study concluded that the stimulation of DNA repair may explain the higher survival cell against UV radiation [139].

Dube and colleagues [140] studied the effect of He-Ne laser $632.8 \mathrm{~nm}$ pre-irradiation on UVA induced DNA damage in the human B-lymphoblast cell line, as measured by comet assay. They found a decrease in UVA-induced DNA damage. Whereas, the control cells showed higher DNA damage, the same rate of DNA damage in He-Ne laser pre-irradiated cells. The results suggest that He-Ne laser irradiation plays an important role in protecting the cells from UVA-induced DNA damage primarily through an influence on processes of preventing an initial damage of DNA [140].

Dillenburg and colleagues [141] triggered epithelial cells with laser phototherapy (LPT) of energy density $4 \mathrm{~J} / \mathrm{cm}^{2}$ and $20 \mathrm{~J} / \mathrm{cm}^{2}$. They observed that laser phototherapy at a low energy density of $4 \mathrm{~J} / \mathrm{cm}^{2}$ did not induce DNA damage or genomic instability, that determined by comet assay. Interestingly, a low energy of LPT induced nuclear influx of the BRCA1 protein of DNA repair, which is a genome protective molecule that effectively takes part in DNA repair. Importantly, these findings suggest that LPT of low dose induces a safe level of reactive oxygen species (ROS), which accelerate healing [141]. 
Ridha and colleagues [142] used a He-Ne laser $632.8 \mathrm{~nm}$ to irradiate human lymphocytes. They concluded that the effect of low red laser light in maintaining cell survival may be attributed to the induction of endogenous radioprotectore and improvement of DNA repair due to induce enzymes involved in repair process [142]. More recently, Trajano and colleagues [143] stated that at therapeutic fluences, exposure to red visible laser therapy alters the expression of genes related to the base excision and nucleotide excision pathways of DNA repair during wound healing [143].

Although, most of the aforementioned studies have been appeared to show the effect of LLLT on cell proliferation, conflicting results have been published. As well, studies tried to explain the induction effect of LLLT on repair mechanisms of DNA damage showed variance results. All these contrasts may be related to a disparity in study design, including the use of different lasers, variations in parameters such as energy densities, wavelengths, exposure time, output power etc.

\section{Discussion}

Interest in the field of LLLT has been rekindled in concert with philosophical evolution toward minimally invasive laser therapies [144]. Although the action of lasers on biological tissue is mediated via photothermal effect, LLLT ideally causes low or imperceptible temperature changes, making LLLT known as" low intensity" or" cold" lasers [41]. Experiments of measuring the temperature following LLLT exposure have shown that the immediate increase in temperature of the irradiated tissue is negligible $\left( \pm 1^{\circ} \mathrm{C}\right)$ [145]. Many researchers emphasises that the temperature remained unchanged in suspensions of different cells through LLLT irradiation [146, 147]. Studies by Schneede and colleagues [148] suggested that the temperature could raise by less than $0.065^{\circ} \mathrm{C}$, during irradiation with laser of $40 \mathrm{~mW} / \mathrm{cm}^{2}$, they used a microthermal probe in a monolayer of cells to measure the temperature [148]. 
Lasers are distinctive and their unique properties of diffraction limited spot of sub-micro dimensions, yielding high power density, ultrashort pulses, coherent radiation (i.e., the light waves are all in phase), and monochromaticity are all made use of [77]. However, many researchers have been found no significant difference for photo stimulation regardless of whether the light used was generated by a laser source or from light of the same wavelength from a filtered incandescent lamp. This review shows an increasing number of papers in the literature on photo therapy in recent years using incoherent light sources, such as LEDs [77, 149].

These findings build on previous reviews of LLLT by including biological effects of LLLT at cellular and molecular levels. Although, various studies included hypotheses explaining the mechanisms of laser action on biological systems, the understanding of the biological effects of laser therapy is still poor. This review has identified a growth in the number of studies. Many studies, often with conflicting results in this field have been published [58]. These discrepancies may be attributed to a variance in study design, including the use of different lasers and inequalities in parameter selection. As well as this, it may, as Karu (1989) indicated, relate to the physiological state of the cell at the moment of irradiation $[58,150]$. In general, for laser studies to be useful, all the characteristics of the light emitted from laser source or by LEDs must be specified [77].

\section{Conclusions}

In conclusion, LLLT is a treatment method using laser light of low energy or intensity. It delivers a very low energy, enough to produce stimulation, but not destruction of the target system; therefore, it has been used extensively for diverse studies. Applications of this optical tool have also attracted criticism with respect to its reproducibility despite, several advantages. The present review has highlighted many subjects included the emergence of 
LLLT, the mechanism of LLLT interaction with the biological system, the optical properties of tissue, the cellular and molecular effect of LLLT as well as, the types of lasers used for LLLT. However, it emerges that most studies concern dose and wavelength. There have only been a limited number of studies so far on the physical parameters of LLLT such as coherence and polarisation of light. The outcomes of this review revealed that, in addition to low intensity coherent lasers, incoherent light emitted from LED, is used widely, with a wide range of therapeutic applications. There were conflicting views as to whether coherent laser or incoherent LED has the most beneficial therapeutic impacts on biological systems. In spite of the large number of studies including different laser types, studies using the same parameters of LLLT to assess cell survival or effects on DNA are so far almost non-existent More studies using LLLT with different properties are needed to investigate which laser with specific properties has a beneficial effect on biological system, in order to be included within the therapeutic tools, and which has a deleterious impact to be excluded from uses (e.g., to treat malignant problems). Furthermore, local magnetic field as magneto-optical phenomenon can change the polarisation dependent absorption of laser light. These aspects need further studies in relation to therapeutic uses of LLLT.

\section{Acknowledgements}

We acknowledge the financial support from the Ministry of Higher Education and Scientific Research, Republic of Iraq (PhD Studentship for RAM).

\section{Conflict of interests}

Authors have no conflicts of interest. 


\section{References}

1. Ginani F, Soares DM, Barboza CAG. 2015. Effect of low-level laser therapy on mesenchymal stem cell proliferation: a systematic review. Lasers in medical science. 30(8): p. 2189-2194.

2. Karu T, 1989. Photobiology of low-power laser effects. Health physics. 56(5): p. 691704.

3. Kreisler M, Christoffers AB, Willershausen B, D'Hoedt B. 2003.Effect of low-level GaAlAs laser irradiation on the proliferation rate of human periodontal ligament fibroblasts: an in vitro study. Journal of clinical periodontology, 30(4): p. 353-358.

4. Posten W, Wrone D, Dover J MD, FRCPC. 2005.Low-level laser therapy for wound healing: mechanism and efficacy. Dermatologic surgery, 31(3): p. 334-340.

5. Lucas C, Criens-Poublon J, Cockrell CT. 2002. Wound healing in cell studies and animal model experiments by Low Level Laser Therapy; were clinical studies justified? A systematic review. Lasers in medical science, 17(2): p. 110-134.

6. King PR, 1989. Low level laser therapy: A review. Lasers in Medical Science, 4(3): p. 141-150.

7. Wu Y-h, Wang J, Gong D, Gu H, Hu S, Zhang H. 2012. Effects of low-level laser irradiation on mesenchymal stem cell proliferation: a microarray analysis. Lasers in medical science. 27(2): p. 509-519.

8. Schindl A, Schindl M, Pernerstorfer H Schindl L. 2000. Low-intensity laser therapy: a review. Journal of investigative medicine: the official publication of the American Federation for Clinical Research. 48(5): p. 312-326.

9. Hamblin MR. 2017. Mechanisms and applications of the anti-inflammatory effects of photobiomodulation. AIMS biophysics. 4(3): p. 337.

10. Anders JJ, Lanzafame RJ. 2015. Arany PR. Low-level light/laser therapy versus photobiomodulation therapy. Mary Ann Liebert, Inc. 140 Huguenot Street, 3rd Floor New Rochelle, NY 10801 USA.

11. Tuner J, Hode L. 2004. The laser therapy handbook. Grängesberg: Prima Books. p. 231.

12. Karu T. 2013. Is it time to consider photobiomodulation as a drug equivalent? Mary Ann Liebert, Inc. 140 Huguenot Street, 3rd Floor New Rochelle, NY 10801 USA.

13. Chung H, Dai T, Sharma SK, Huang YY. 2012. The nuts and bolts of low-level laser (light) therapy. Annals of biomedical engineering. 40(2): p. 516-533.

14. Bjordal JM, Couppe C, Chow RT. 2003.A systematic review of low level laser therapy with location-specific doses for pain from chronic joint disorders. Journal of Physiotherapy. 49(2): p. 107-116.

15. Gigo-Benato D, Geuna S, and Rochkind S. 2005. Phototherapy for enhancing peripheral nerve repair: a review of the literature. Muscle \& nerve. 31(6): p. 694-701.

16. Barrett D and Gonzalez-Lima F. 2013. Transcranial infrared laser stimulation produces beneficial cognitive and emotional effects in humans. Neuroscience. 230: p. 13-23.

17. Salehpour F and Rasta SH. 2017. The potential of transcranial photobiomodulation therapy for treatment of major depressive disorder. Reviews in the Neurosciences. 28(4): p. 441-453.

18. Xuan W, Vatansever F, Huang L.2014. Transcranial low-level laser therapy enhances learning, memory, and neuroprogenitor cells after traumatic brain injury in mice. Journal of biomedical optics. 19(10): p. 108003. 
19. Salehpour F, Ahmadian N, Rasta SH . 2017. Transcranial low-level laser therapy improves brain mitochondrial function and cognitive impairment in D-galactoseinduced aging mice. Neurobiology of aging. 58: p. 140-150.

20. Naeser MA, Saltmarche A, Krengel MH. 2011. Improved cognitive function after transcranial, light-emitting diode treatments in chronic, traumatic brain injury: two case reports. Photomedicine and laser surgery. 29(5): p. 351-358.

21. Tsai S-R and MR Hamblin. 2017.Biological effects and medical applications of infrared radiation. Journal of Photochemistry and Photobiology B: Biology. 170: p. 197-207.

22. Fonseca AS, TO Moreira, DL Paixão. 2010. Effect of laser therapy on DNA damage. Lasers in surgery and medicine. 42(6): p. 481-488.

23. Ratkay-Traub I, Hopp B, Bor ZS, Dux L. 2001.Regeneration of rabbit cornea following excimer laser photorefractive keratectomy: a study on gap junctions, epithelial junctions and epidermal growth factor receptor expression in correlation with cell proliferation. Experimental eye research. 73(3): p. 291-302.

24. Hawkins D, Houreld N, and Abrahamse H. 2005. Low level laser therapy (LLLT) as an effective therapeutic modality for delayed wound healing. Annals of the New York Academy of Sciences. 1056(1): p. 486-493.

25. Hawkins D, Abrahamse H. 2006. Laboratory methods for evaluating the effect of low level laser therapy (LLLT) in wound healing. African journal of biomedical research. 8(1): p. 1-14.

26. da Silva Sergio L, da Silva Marciano R. 2012. Evaluation of DNA damage induced by therapeutic low-level red laser. J Clin Exp Dermatol Res. 3: p. 166.

27. Vasheghani MM, Bayat M, Dadpay M. 2009. Low-level laser therapy using 80-Hz pulsed infrared diode laser accelerates third-degree burn healing in rat. Photomedicine and laser surgery. 27(6): p. 959-964.

28. de Meneses SRF, Hunter DJ. 2015. Effect of low-level laser therapy $(904 \mathrm{~nm})$ and static stretching in patients with knee osteoarthritis: a protocol of randomised controlled trial. BMC musculoskeletal disorders. 16(1): p. 252.

29. Bayat M, et al. 2016. An evaluation of the effect of pulsed wave low-level laser therapy on the biomechanical properties of the vertebral body in two experimental osteoporosis rat models. Lasers in medical science. 31(2): p. 305-314.

30. Ahrari F, Madani AS, Ghafouri ZS, Tunér J. 2014. The efficacy of low-level laser therapy for the treatment of myogenous temporomandibular joint disorder. Lasers in medical science. 29(2): p. 551-557.

31. Hashmi JT, Huang YY, Sharma SK. 2010. Effect of pulsing in low-level light therapy. Lasers in surgery and medicine. 42(6): p. 450-466.

32. Amid R, Kadkhodazadeh M, Ahsaie MG. 2014. Effect of Low Level Laser Therapy on Proliferation and Differentiation of the Cells Contributing in Bone Regeneration: A Systematic Review. Journal of lasers in medical sciences, 5(4): p. 163.

33. McDaniel DH. 2015. Low intensity light therapy for treatment of retinal, macular, and visual pathway disorders. Google Patents.

34. Surendranath P and Arjun K. 2013. Low Level Laser Therapy-A Review. IOSR-JDMS. 12: p. 56-9.

35. Nelson J. 1993.Lasers: state of the art in dermatology. Dermatologic clinics. 11(1): p. 15-26.

36. Bjordal JM, Couppe C, Ljunggren AE. 2001. Low level laser therapy for tendinopathy. Evidence of a dose-response pattern. Physical Therapy Reviews. 6(2): p. 91-99. 
37. Brondon, P, Stadler I, Lanzafame RJ. 2005. A study of the effects of phototherapy dose interval on photobiomodulation of cell cultures. Lasers in surgery and medicine. 36(5): p. 409-413.

38. Mochizuki-Oda N, Kataoka Y, Cui Y, Yamada H. 2002. Effects of near-infra-red laser irradiation on adenosine triphosphate and adenosine diphosphate contents of rat brain tissue. Neuroscience letters. 323(3): p. 207-210.

39. Karu T. 1999. Primary and secondary mechanisms of action of visible to near-IR radiation on cells. Journal of Photochemistry and photobiology B: Biology. 49(1): p. $1-17$.

40. Karu TI. 2001. Afanasyeva NI, Kolyakov SF. Changes in absorbance of monolayer of living cells induced by laser radiation at 633, 670, and $820 \mathrm{~nm}$. Selected Topics in Quantum Electronics, IEEE Journal of. 7(6): p. 982-988.

41. Hamblin MR, Demidova TN. 2006. Mechanisms of low level light therapy. in Biomedical Optics 2006. International Society for Optics and Photonics.

42. Karu TI. 2008. Mitochondrial signaling in mammalian cells activated by red and near-IR radiation. Photochemistry and photobiology. 84(5): p. 1091-1099.

43. de Freitas LF and Hamblin MR. 2016. Proposed mechanisms of photobiomodulation or low-level light therapy. IEEE Journal of selected topics in quantum electronics. 22(3): p. 348-364.

44. Irvine RF, Schell MJ. 2001. Back in the water: the return of the inositol phosphates. Nature reviews Molecular cell biology. 2(5): p. 327.

45. Santana-Blank LA, Rodríguez-Santana E, K.E. Santana-Rodríguez. 2005. Photoinfrared pulsed bio-modulation (PIPBM): a novel mechanism for the enhancement of physiologically reparative responses. Photomedicine and Laser Therapy. 23(4): p. 416-424.

46. Wang Y, Huang YY, Wang Y, Lyu P, Hamblin MR. 2016. Photobiomodulation (blue and green light) encourages osteoblastic-differentiation of human adipose-derived stem cells: role of intracellular calcium and light-gated ion channels. Scientific reports. 6: p. 33719.

47. Roska B Lagali P. 2018. Retinal on bipolar cells-specific artificial promoter. Google Patents.

48. Kulbacka J, Choromańska A, Rossowska J. 2017. Cell Membrane Transport Mechanisms: Ion Channels and Electrical Properties of Cell Membranes, in Transport Across Natural and Modified Biological Membranes and its Implications in Physiology and Therapy. Springer. p. 39-58.

49. Roska B, Juettner J. 2017. Aii retinal amacrine cell-specific promoter. Google Patents.

50. Schneider F, Grimm C, and Hegemann P. 2015. Biophysics of channelrhodopsin. Annual review of biophysics. 44: p. 167-186.

51. Amid R, Kadkhodazadeh M, Ahsaie MG. 2013. Effect of low level laser therapy on proliferation and differentiation of the cells contributing in bone regeneration. Journal of lasers in medical sciences. 5(4): p. 163-170.

52. Basso FG, Oliveira CF, Kurachi C, Hebling J. 2013. Biostimulatory effect of low-level laser therapy on keratinocytes in vitro. Lasers in medical science. 28(2): p. 367-374.

53. Koutná M, Janisch R, Veselska R. 2003. Effects of low-power laser irradiation on cell proliferation. Scripta Medica, 76(3): p. 163-72.

54. Thompson R. 1988.Lasers: Principles and Applications.

55. Singh SC, Zeng H, Guo C. 2012. Lasers: Fundamentals, types, and operations. Nanomaterials: Processing and Characterization with Lasers. p. 1-34. 
56. Karu TI, Pyatibrat LV, and Afanasyeva NI. 2004. A Novel Mitochondrial Signaling Pathway Activated by Visible-to-near Infrared Radiation. Photochemistry and photobiology. 80(2): p. 366-372.

57. Mbene AB. 2008. EFFECT OF LOW LEVEL LASER THERAPY ON GENE ACTIVATION, DNA DAMAGE AND REPAIR USING 5 OR $16 \mathrm{~J} / \mathrm{cm} 2 \quad$ ON WOUNDED HUMAN SKIN FIBROBLAST CELLS. Faculty of Health Sciences, University of Johannesburg.

58. Smith KC. 991.The photobiological basis of low level laser radiation therapy. Laser Therapy. 1 3(1): p. 19-24.

59. AlGhamdi KM, Kumar A, Moussa NA. 2012. Low-level laser therapy: a useful technique for enhancing the proliferation of various cultured cells. Lasers in medical science. 27(1): p. 237-249.

60. Tafur J, Mills PJ. 2008. Low-intensity light therapy: Exploring the role of redox mechanisms. Photomedicine and laser surgery,. 26(4): p. 323-328.

61. Avci P, Gupta GK, Clark J, Wikonkal N. 2013. Low-level laser (light) therapy (LLLT) in skin: stimulating, healing, restoring. in Seminars in cutaneous medicine and surgery. NIH Public Access.

62. Huang Y-Y, Chen ACH, Carroll JD . 2009. Biphasic dose response in low level light therapy. Dose-Response, 7(4): p. dose-response. 09-027. Hamblin.

63. Di Giacomo P, et al. 2013. Low Level Laser Therapy: laser radiation absorption in biological tissues. Applied Physics A, 112(1): p. 71-75.

64. Silveira PC, et al. 2009. Evaluation of mitochondrial respiratory chain activity in muscle healing by low-level laser therapy. Journal of Photochemistry and Photobiology B: Biology. 95(2): p. 89-92.

65. Sergio LPdS, et al. 2015. DNA damage in blood cells exposed to low-level lasers. Lasers in surgery and medicine. 47(4): p. 361-368.

66. Canuto $\mathrm{K}$, et al. 2015. Low-level red laser therapy alters effects of ultraviolet $C$ radiation on Escherichia coli cells. Brazilian Journal of Medical and Biological Research. 48(10): p. 939-944.

67. Continenza M, Ricciardi G, Franchitto A. 1993. Effects of low power $904 \mathrm{~nm}$ radiation on rat fibroblasts explanted and in vitro cultured. Journal of Photochemistry and Photobiology B: Biology. 19(3): p. 231-234.

68. Lettnin AP, et al. 2016.Protective effect of infrared-A radiation against damage induced by UVB radiation in the melan-a cell line. Journal of Photochemistry and Photobiology B: Biology. 163: p. 125-132.

69. Niemz MH. 2013. Laser-tissue interactions: fundamentals and applications.: Springer Science \& Business Media.

70. Jacques SL. 2013. Optical properties of biological tissues: a review. Physics in medicine and biology, 58(11): p. R37.

71. palan, PAQ-SaVV. 2007. Mechanisms of Laser Interactions, PART II, Mechanisms of Laser Cellular Microsurgery. METHODS IN CELL BIOLOGY. 82(Elsevier Inc.): p. 113-151.

72. Chandrasekhar S. 1960. Radiative heat transfer. Dover Publications, New York, 11: p. 11-12.

73. Lenoble J. 1985. Radiative transfer in scattering and absorbing atmospheres: standard computational procedures. Vol. 1.: A. Deepak Hampton, VA.

74. Cheong W, Prahl S, Welch A. 1990. A review of the optical properties of biological. iEEE J. Quantum Electronics. 26: p. 2166-2185. 
75. Hashmi JT, et al. 2010. Role of low-level laser therapy in neurorehabilitation. PM\&R. 2(12): p. S292-S305.

76. Huang, Y-Y, et al. 2011. Biphasic dose response in low level light therapy-an update. Dose-Response. 9(4): p. dose-response. 11-009. Hamblin.

77. Smith KC. Low-level laser or led therapy is phototherapy.

78. Karu TI. 2010. Multiple roles of cytochrome c oxidase in mammalian cells under action of red and IR-A radiation. IUBMB life. 62(8): p. 607-610.

79. Piazena H, Kelleher DK. 2010. Effects of Infrared-A Irradiation on Skin: Discrepancies in Published Data Highlight the Need for an Exact Consideration of Physical and Photobiological Laws and Appropriate Experimental Settings. Photochemistry and photobiology. 86(3): p. 687-705.

80. Smith KC. 2007. Ten lectures on basic science of laser phototherapy. Photochemistry and Photobiology. 83(6): p. 1539-1540.

81. Desmet KD, et al. 2006. Clinical and experimental applications of NIR-LED photobiomodulation. Photomedicine and Laser Therapy. 24(2): p. 121-128.

82. Habash RW, et al. 2006. Thermal therapy, part 1: an introduction to thermal therapy. Critical Reviews ${ }^{\mathrm{TM}}$ in Biomedical Engineering. 34(6).

83. Woodruff LD, et al. 2004. The efficacy of laser therapy in wound repair: a metaanalysis of the literature. Photomedicine and laser surgery. 22(3): p. 241-247.

84. Brown GC. 1995. Nitric oxide regulates mitochondrial respiration and cell functions by inhibiting cytochrome oxidase. FEBS letters. 369(2-3): p. 136-139.

85. Lane N. 2006. Cell biology: power games. Nature Publishing Group.

86. Alexandratou E, et al. 2002. Human fibroblast alterations induced by low power laser irradiation at the single cell level using confocal microscopy. Photochemical \& Photobiological Sciences. 1(8): p. 547-552.

87. Lavi R, et al. 2003. Low energy visible light induces reactive oxygen species generation and stimulates an increase of intracellular calcium concentration in cardiac cells. Journal of Biological Chemistry, 278(42): p. 40917-40922.

88. Lubart R, et al. 2005. Low-energy laser irradiation promotes cellular redox activity. Photomedicine and Laser Therapy. 23(1): p. 3-9.

89. Zhang J, Xing D, Gao X. 2008. Low-power laser irradiation activates Src tyrosine kinase through reactive oxygen species-mediated signaling pathway. Journal of cellular physiology. 217(2): p. 518-528.

90. Cotler HB, et al. 2015. The use of low level laser therapy (LLLT) for musculoskeletal pain. MOJ orthopedics \& rheumatology. 2(5).

91. Gilmore TD. 2006. Introduction to NF- $\kappa B$ : players, pathways, perspectives. Oncogene. 25(51): p. 6680.

92. Han KY, et al. 2011. Light emitting diode package and light emitting diode system having at least two heat sinks. Google Patents.

93. Suparman J. 2013. Invention History Light Emitting Diode LED by Henry Round,Oleg Losev: p. 4.

94. de Abreu Chaves ME, et al. 2014. Laser and LED-Comparison of Effects. An Bras Dermatol. 89(4): p. 616-623.

95. Ishida M. 2005. Light emitting diode (LED). Google Patents.

96. Molinaroli CJ. 2001. Light emitting diode display device. Google Patents.

97. McDaniel D, et al. 2003. Non-ablative non-thermal LED photomodulation-A multicenter clinical photoaging trial. in Lasers in Surgery and Medicine. WILEYLISS DIV JOHN WILEY \& SONS INC, 605 THIRD AVE, NEW YORK, NY 10158-0012 USA. 
98. Agnol MAD, et al. 2009. Comparative analysis of coherent light action (laser) versus non-coherent light (light-emitting diode) for tissue repair in diabetic rats. Lasers in medical science. 24(6): p. 909-916.

99. Darren Starwynn O. 2004. LAc Laser and LED Treatments: Which Is Better? Acupuncture Today. 05(06).

100. Kubota J, Ohshiro T. 2004. The effects of diode laser LLLT on flap survival: measurement of flap microcirculation with laser speckle flowmetry. Laser Therapy. 14(0_Pilot_Issue_2): p. 0_55-0_60.

101. Berki T, Nemeth P, Hegedüs J. 1988. Biological effect of low-power helium-neon (HeNe) laser irradiation. Lasers in Medical Science, 3(1-4): p. 35-39.

102. Haina D, et al. 1982. Animal experiments on light-induced woundhealing, in Optoelectronics in Medicine. Springer. p. 164-169.

103. Rochkind S, Nissan M, Lubart A. 1989. A single transcutaneous light irradiation to injured peripheral nerve: comparative study with five different wavelengths. Lasers in Medical Science. 4(4): p. 259-263.

104. Laakso EL. et al. 1994. Plasma ACTH and $\beta$-endorphin levels in response to low level laser therapy (LLLT) for myofascial trigger points. Laser Therapy. 6(3): p. 133141.

105. Lederer H, et al. 1982. Influence of light on human immunocompetent cells in vitro, in Optoelectronics in Medicine. Springer. p. 170-184.

106. al. NJHe. 1989. The role of coherence in wound healing stimulation by non-thermal laser irradiation. Surgical and Medical Lasers. 2-3(2): p. 1.

107. Sommer AP, et al. 2001. Biostimulatory windows in low-intensity laser activation: lasers, scanners, and NASA's light-emitting diode array system. Journal of clinical laser medicine \& surgery. 19(1): p. 29-33.

108. Oliveira Sampaio SC dCMJ. 2012. Cangussú MC, Pires Santos GM, Dos Santos MA, Dos Santos JN, Pinheiro AL., Effect of laser and LED phototherapies on the healing of cutaneous wound on healthy and iron-deficient Wistar rats and their impact on fibroblastic activity during wound healing. Laser Med Sci.

109. Esper MA, Arisawa NR, EA. 2011. The effect of two phototherapy protocols on pain control in orthodontic procedure-a preliminary clinical study. Laser Med Sci.

110. Dall Agnol MA, NR, de Lima CJ, Munin E. 2009. Comparative analysis of coherent light action (laser) versus non-coherent light (light-emitting diode) for tissue repair in diabetic rats. Laser Med Sci. 24(6).

111. Klebanov GI, SN, Chichuk TV, Osipov AN, Rudenko TG, Shekhter AB, Vladimirov IuA, 2005. A comparative study of the effects of laser and light-emtting diode irradiation on the wound healing and functional activity of wound exudate leukocytes. Biofizika. 50(6).

112. Klebanov GI, SN, Chichuk TV, Osipov AN, Vladimirov IuA. 2006. A comparison of the effects of laser and light-emitting diodes on superoxide dismutase and nitric oxide production in rat wound fluid. Biofizika. 51(1).

113. Yeh NG, Wu C-H, Cheng T.C. 2010. Light-emitting diodes-Their potential in biomedical applications. Renewable and Sustainable Energy Reviews. 14(8): p. 21612166.

114. Ghuloom, M. 2013. The Effect of Light Emitting Diode (LED) on the Healing of Endosseous Intraoral Implants.

115. Oliveira RG, et al. 2013. Low-level laser reduces the production of TNF- $\alpha$, IFN- $\gamma$, and IL-10 induced by OVA. Lasers in medical science. 28(6): p. 1519-1525. 
116. Lee SY, et al. 2007. A prospective, randomized, placebo-controlled, double-blinded, and split-face clinical study on LED phototherapy for skin rejuvenation: clinical, profilometric, histologic, ultrastructural, and biochemical evaluations and comparison of three different treatment settings. Journal of Photochemistry and Photobiology B: Biology. 88(1): p. 51-67.

117. Avci P, et al. 2014. Low-level laser (light) therapy (LLLT) for treatment of hair loss. Lasers in surgery and medicine. 46(2): p. 144-151.

118. Bell L, Stout N.L. 2018. Using Low-Level Light Laser in Your Lymphedema Practice: Benefits and Cautions. Rehabilitation Oncology. 36(1): p. 70-72.

119. Corazza AV, et al. 2007. Photobiomodulation on the angiogenesis of skin wounds in rats using different light sources. Photomedicine and laser surgery. 25(2): p. 102-106.

120. Xavier M, et al. 2010. Anti-inflammatory effects of low-level light emitting diode therapy on achilles tendinitis in rats. Lasers in surgery and medicine. 42(6): p. 553558.

121. Leal Junior ECP, et al. 2009. Comparison between single-diode low-level laser therapy (LLLT) and LED multi-diode (cluster) therapy (LEDT) applications before high-intensity exercise. Photomedicine and laser surgery. 27(4): p. 617-623.

122. Karu T, Pyatibrat L, Kalendo G. 1994. Irradiation with He-Ne laser can influence the cytotoxic response of $\mathrm{HeLa}$ cells to ionizing radiation. International journal of radiation biology. 65(6): p. 691-697.

123. Pereira AN, et al. 2002. Effect of low-power laser irradiation on cell growth and procollagen synthesis of cultured fibroblasts. Lasers in surgery and medicine. 31(4): p. 263-267.

124. Medrado AR, et al. 2003. Influence of low level laser therapy on wound healing and its biological action upon myofibroblasts. Lasers in surgery and medicine. 32(3): p. 239-244.

125. Bouma MG, Buurman WA, van den Wildenberg FA. 1996. Low energy laser irradiation fails to modulate the inflammatory function of human monocytes and endothelial cells. Lasers in surgery and medicine. 19(2): p. 207-215.

126. Schindl A., et al. 2003. Direct stimulatory effect of low-intensity $670 \mathrm{~nm}$ laser irradiation on human endothelial cell proliferation. British Journal of Dermatology. 148(2): p. 334-336.

127. Haas AF, et al. 1990. Low-energy helium-neon laser irradiation increases the motility of cultured human keratinocytes. Journal of investigative dermatology. 94(6): p. 822-826.

128. Grossman $\mathrm{N}$, et al. 1998. $780 \mathrm{~nm}$ low power diode laser irradiation stimulates proliferation of keratinocyte cultures: involvement of reactive oxygen species. Lasers in surgery and medicine. 22(4): p. 212-218.

129. Walsh L. 1997. The current status of low level laser therapy in dentistry, Part 1. Soft tissue applications. Australian dental journal. 42(4): p. 247-254.

130. Petri AD, et al. 2010. Effects of low-level laser therapy on human osteoblastic cells grown on titanium. Brazilian dental journal. 21(6): p. 491-498.

131. Forouzanfar A. 2014. The Effects of Low Level Laser Therapy on the Expression of Collagen Type I Gene and Proliferation of Human Gingival Fibroblasts (Hgf3-Pi 53): in vitro Study. International Journal of Pediatrics. 2(2.3): p. 65-65.

132. Tuby H, Maltz L, U. 2007. Oron, Low-level laser irradiation (LLLI) promotes proliferation of mesenchymal and cardiac stem cells in culture. Lasers in surgery and medicine. 39(4): p. 373-378. 
133. Almeida-Lopes, L, et al. 2001. Comparison of the low level laser therapy effects on cultured human gingival fibroblasts proliferation using different irradiance and same fluence*. Lasers in surgery and medicine. 29(2): p. 179-184.

134. Kujawa J, et al. 2004. Cell survival, DNA, and protein damage in B14 cells under lowintensity near-infrared $(810 \mathrm{~nm})$ laser irradiation. Photomedicine and Laser Therapy. 22(6): p. 504-508.

135. Albertini R, et al. 2008. Cytokine mRNA expression is decreased in the subplantar muscle of rat paw subjected to carrageenan-induced inflammation after low-level laser therapy. Photomedicine and laser surgery. 26(1): p. 19-24.

136. Kong X, et al. 2009.Comparative analysis of different laser systems to study cellular responses to DNA damage in mammalian cells. Nucleic acids research. 37(9): p. e68e68.

137. Zhang Y, et al. 2003. cDNA microarray analysis of gene expression profiles in human fibroblast cells irradiated with red light. Journal of Investigative Dermatology. 120(5): p. 849-857.

138. da Silva Sergio LP, et al. 2012. Evaluation of DNA Damage Induced by Therapeutic Low-Level Red Laser. Journal of Clinical \& Experimental Dermatology Research.

139. Kohli R, Bose B, Gupta PK. 2001. Induction of phr gene expression in E. coli strain KY706/pPL-1 by He-Ne laser $(632.8 \mathrm{~nm})$ irradiation. Journal of Photochemistry and Photobiology B: Biology. 60(2): p. 136-142.

140. Dube A, et al. 2001. He-Ne laser irradiation protects B-lymphoblasts from UVAinduced DNA damage. Radiation and environmental biophysics. 40(1): p. 77-82.

141. Dillenburg CS, et al. 2014. Laser phototherapy triggers the production of reactive oxygen species in oral epithelial cells without inducing DNA damage. Journal of biomedical optics. 19(4): p. 048002-048002.

142. Ridha FD, Salih A, Abdul-Majeed B.A. 2012. The effect of Laser radiation on DNA damage and repair. Fac. Med. Baghdad. 54(2): p. 163-166.

143. Trajano ETL, et al. 2014. Expression of DNA repair genes in burned skin exposed to low-level red laser. Lasers in medical science. 29(6): p. 1953-1957.

144. Alam M Dover J. 2003. Nonablative laser and light therapy: an approach to patient and device selection. Skin Therapy Lett. 8(4): p. 4-7.

145. Hrnjak M, et al. 1994. Stimulatory effect of low-power density He-Ne laser radiation on human fibroblasts in vitro. Vojnosanitetski pregled. 52(6): p. 539-546.

146. Boulton M, Marshall J. 1986. He-Ne laser stimulation of human fibroblast proliferation and attachment in vitro. Lasers in the life sciences. 1(2): p. 125-134.

147. Quickenden T, Danniels L. 1993. Attempted biostimulation of division in Saccharomyces cerevisiae using red coherent light. Photochemistry and photobiology. 57(2): p. 272-278.

148. Schneede P, et al. 1988. Effects of the helium-neon laser on rat kidney epithelial cells in culture. Lasers in Medical Science. 3(1-4): p. 249-257.

149. Smith KC. 2005. Laser (and LED) therapy is phototherapy. Photomedicine and Laser Therapy. 23(1): p. 78-80.

150. KARU T. 1989. Laser biostimulation: a photobiological phenomenon. 
Table1. Review of published studies using Low Level Laser Therapy (LLLT) to treat different diseases.

\begin{tabular}{|c|c|c|c|c|c|c|c|c|}
\hline $\begin{array}{l}\text { Study } \\
\text { No. }\end{array}$ & Type of laser & $\begin{array}{l}\text { Wavelength } \\
(\mathrm{nm})\end{array}$ & $\begin{array}{l}\text { Power } \\
(\mathrm{mW})\end{array}$ & $\begin{array}{l}\text { Energy density } \\
\left(\mathrm{J} / \mathrm{cm}^{2}\right)\end{array}$ & $\begin{array}{l}\text { Power } \\
\text { density } \\
\left(\mathrm{mW} / \mathrm{cm}^{2}\right)\end{array}$ & $\begin{array}{l}\text { Emission } \\
\text { model } \\
\text { CW / Pulse }\end{array}$ & Types of diseases & Reference \\
\hline 1 & Diode laser & 810 & $10 \mathrm{~W}$ & 3 and 30 & 5 and 50 & $\mathrm{CW}$ & Zymosan-induced arthritis & Castano et al. [16] \\
\hline 2 & $\mathrm{He}-\mathrm{Ne}$ & 632.8 & 10 & $\begin{array}{l}3,5,10,20 \\
25 \text { and } 50\end{array}$ & 64.6 & $\mathrm{CW}$ & Neurodegenerative & Song et al. [17] \\
\hline 3 & $\mathrm{He}-\mathrm{Ne}$ & 632.8 & 10 & $0.5,1,2$ and 4 & & $\mathrm{CW}$ & Alzheimer's disease & Meng et al. [18] \\
\hline 4 & $\mathrm{Nd}: Y A G$ & 1064 & $1.25 \mathrm{~W}$ & & & $\mathrm{CW}$ & Dental/Tooth extraction & Vescovi et al. [19] \\
\hline 5 & GaAs & 904 & 10 & 5.4 & 20 & $\mathrm{CW}$ & Musculoskeletal diseases & Bjordal et al. [20] \\
\hline 6 & Diode laser & 830 & 30 & 1.1 & & Pulse & Painful stomatitis control & Toida et al. [21] \\
\hline 7 & Diode laser & 810 & 30 & 0.9 & 30 & $\mathrm{CW}$ & Diabetic wounds & Dancakova et al. [22] \\
\hline 8 & $\begin{array}{l}\text { Diode laser } \\
\mathrm{He}-\mathrm{Ne}\end{array}$ & $\begin{array}{l}830 \\
632.8\end{array}$ & $\begin{array}{l}30 \\
20\end{array}$ & & 4 & $\mathrm{CW}$ & Chronic diseases of inner ear & Wilden et al. [23] \\
\hline 9 & Diode laser & 660 & 50 & 2 & & $\mathrm{CW}$ & $\begin{array}{l}\text { Chronic lichenoid graft-vs.-host } \\
\text { disease (cGVHD) }\end{array}$ & Chor et al. [24] \\
\hline 10 & Diode laser & 810 & & 3 & 20 & CW & Cortical neurons & Huang et al. [25] \\
\hline 11 & $\mathrm{He}-\mathrm{Ne}$ & 632.8 & 400 & 1 & & $\mathrm{CW}$ & Alzheimer's Disease & Farfara et al. [26] \\
\hline 12 & GaAlAs & 860 & $\begin{array}{l}30 \\
60\end{array}$ & 3 & 3000 & $\begin{array}{l}\text { Pulse } \\
\text { CW }\end{array}$ & Osteoarthritic (OA) pain & Brosseau et al. [27] \\
\hline 13 & GaAs & 808 & & & 10 and 20 & $\mathrm{CW}$ & Traumatic brain injury (TBI) & Oron et al. [28] \\
\hline 14 & GaAlAs & 830 & 60 & 45 & 4000 & $\mathrm{CW}$ & Lumbago & Ohshiro et al. [29] \\
\hline 15 & Diode laser & 660 & 30 & 7.5 & & $\mathrm{CW}$ & Lung neutrophils & Aimbire et al. [30] \\
\hline 16 & Diode laser & 660 & 40 & 20 & & $\mathrm{CW}$ & Burning mouth syndrome & Santos et al. [31] \\
\hline 17 & Diode laser & $\begin{array}{l}665,730 \\
810 \text { and } 980\end{array}$ & & 36 & 150 & $\mathrm{CW}$ & Traumatic brain injury (TBI) & Wu Qiuhe et al. [32] \\
\hline 18 & Diode laser & 660 & 24 & & & $\mathrm{CW}$ & Periodontal disease & de Almeida et al. [33] \\
\hline
\end{tabular}


Table1. Continued

\begin{tabular}{|c|c|c|c|c|c|c|c|c|}
\hline 19 & Diode laser & 820 & 300 & 3 & & CW & $\begin{array}{l}\text { myofascial pain (MP) } \\
\text { dysfunction syndrome }\end{array}$ & Oz Selcen et al. [34] \\
\hline 20 & GaAlAs & 780 & 50 & 7.5 & & $\mathrm{CW}$ & Rheumatoid arthritis & Ekim et al. [35] \\
\hline 21 & Diode laser & 810 & $>$ & $\begin{array}{l}0.03,0.3,3,10 \text { and } \\
30\end{array}$ & 25 & $\mathrm{CW}$ & Cortical neurons & Sharma et al. [36] \\
\hline 22 & GaAlAs & 830 & 70 & 6 & & $\mathrm{CW}$ & Peripheral nerves regeniration & Midamba et al. [37] \\
\hline 23 & GaAlAs & 810 & $1 \mathrm{~W}$ & $\begin{array}{l}4.8 \\
24\end{array}$ & 80 & $\mathrm{CW}$ & Orofacial granulomatosis & Merigo et al. [38] \\
\hline 24 & Diode laser & 830 & 100 & 3 & & $\mathrm{CW}$ & Chronic periodontitis & Makhlouf et al. [39] \\
\hline 25 & Diode laser & $\begin{array}{l}780 \\
830\end{array}$ & $\begin{array}{l}30 \\
500\end{array}$ & $\begin{array}{l}6.3 \\
100\end{array}$ & & $\mathrm{CW}$ & Temporomandibular joint pain & Chang et al. [40] \\
\hline 26 & $\mathrm{He}-\mathrm{Ne}$ & 632.8 & 10 & $0.18-27$ & & $\mathrm{CW}$ & Indolent ulcers & Schindl et al. [41] \\
\hline 27 & Diode laser & 808 & & & $\begin{array}{l}110 \\
165\end{array}$ & $\mathrm{CW}$ & Hearing loss & Tamura et al. [42] \\
\hline 28 & Diode laser & $\begin{array}{l}532 \\
635\end{array}$ & 7.5 & & & $\begin{array}{l}\text { CW } \\
\text { Pulse }\end{array}$ & Hearing loss & Goodman et al. [43] \\
\hline 29 & Diode laser & 650 & 5 & & & $\mathrm{CW}$ & Complaints of Tinnitus & Salahaldin et al. [44] \\
\hline 30 & InGaAIP & 660 & 10 & 2.5 & & $\mathrm{CW}$ & Acute zymosan-induced arthritis & Carlos et al. [45] \\
\hline 31 & GaAs & 904 & 20 & $2-20$ & 11.2 & Pulse & $\begin{array}{l}\text { chronic myofascial pain syndrome } \\
\text { (MPS) in the neck }\end{array}$ & Gur et al. [46] \\
\hline 32 & GaAs & 904 & & 29.5 & 246 & Pulse & Salivary Glands (Xerostomia) & Loncar et al. [47] \\
\hline 33 & Diode laser & $\begin{array}{l}630-670 \\
780-830\end{array}$ & $10-100$ & 2,3 and 4 & & $\mathrm{CW}$ & $\begin{array}{l}\text { Oral mucositis due to cancer } \\
\text { therapy }\end{array}$ & Bensadoun et al. [48] \\
\hline 34 & Diode laser & $\begin{array}{l}660,810 \text { and } \\
980\end{array}$ & & 36 & & $\mathrm{CW}$ & Traumatic brain injury (TBI) & Wu Qiuhe et al. [49] \\
\hline 35 & GaAlAs & 670 & 5 & 2 & & $\mathrm{CW}$ & $\begin{array}{l}\text { Chronic periodontitis } \\
\text { Diabetes mellitus (DM) }\end{array}$ & Obradovic et al. [50] \\
\hline 36 & Ga-AsI-Al & 780 & 22 & 7.7 & 100 & $\mathrm{CW}$ & Rheumatoid arthritis (RA) & Alves et al. [51] \\
\hline
\end{tabular}


Table1. Continued

\begin{tabular}{|c|c|c|c|c|c|c|c|c|}
\hline 37 & Diode laser & 810 & & 36 & 50 & CW & Traumatic brain injury (TBI) & Xuan et al. [52] \\
\hline 38 & $\begin{array}{l}\text { Diode laser } \\
\text { LED }\end{array}$ & $\begin{array}{l}685 \\
640-685\end{array}$ & 200 & 2 & & $\mathrm{CW}$ & Reynaud's phenomenon & Hirschl et al. [53] \\
\hline 39 & Diode laser & 810 & & & 50 & $\mathrm{CW}$ & Parkinson's disease (PD) & Trimmer et al. [54] \\
\hline 40 & Diode laser & 790 & 120 & 6 & & $\mathrm{CW}$ & Burning mouth syndrome & Kato et al. [55] \\
\hline 41 & IR laser & 830 & 35 & 3 & & $\mathrm{CW}$ & Lung inflammation & Oliveira et al. [56] \\
\hline 42 & GaAs & 904 & 150 & 6 & & Pulse & Carpal tunnel syndrome & Dakowicz et al. [57] \\
\hline 43 & AlGaAs & 780 & 30 & 22.5 & 750 & $\begin{array}{l}\text { CW } \\
\text { Pulse } \\
\text { Pulse }\end{array}$ & Renal Interstitial Fibrosis & Oliveira et al. [58] \\
\hline 44 & GaAlAs & 830 & 60 & 18 & 3000 & CW & Knee Osteoarthrosis & Trelles et al. [59] \\
\hline 45 & AlGaAs & 785 & 70 & 3 & & CW & Rheumatoid arthritis & Meireles et al. [60] \\
\hline 46 & Diode laser & 670 & 50 & 3 & & Pulse & $\begin{array}{l}\text { Temporomandibular disorder } \\
\text { (TMD) }\end{array}$ & Nunez et al. [61] \\
\hline 47 & GaAs & 904 & 45 & 5 & & $\mathrm{CW}$ & Muscle trauma & Rizzi et al . [62] \\
\hline 48 & GaAlAs & 980 & 300 & 4 & 1500 & $\mathrm{CW}$ & Mucous membrane pemphigoid & Cafaro et al. [63] \\
\hline 49 & Diode laser & 660 & 5 & 4.5 & & CW & Acut Lung inflammation & de Lima et al. [64] \\
\hline 50 & GaAs & 980 & $\begin{array}{l}10 \\
80 W\end{array}$ & $2-4$ & & $\begin{array}{l}\text { CW } \\
\text { Pulse }\end{array}$ & Chronic low back pain (LBP) & Hadi et al. [65] \\
\hline 51 & GaAlAs & 980 & 300 & 4 & 1000 & CW & Oral lichen planus & Cafaro et al. [66] \\
\hline
\end{tabular}


Table1. Continued

\begin{tabular}{|c|c|c|c|c|c|c|c|c|}
\hline 52 & GaAlAs & 660 & 30 & 57.14 & 428 & $\mathrm{CW}$ & Periodontal disease (PD) & Garcia et al. [67] \\
\hline 53 & InGaAlP & 660 & 40 & 2 & 1000 & $\mathrm{CW}$ & $\begin{array}{l}\text { Ulcers in patients with leprosy } \\
\text { sequelae }\end{array}$ & Barreto et al. [68] \\
\hline 54 & GaAlAs & 815 & 250 & 12 & & $\mathrm{CW}$ & $\begin{array}{l}\text { inflammation in retrodiscal tissues in } \\
\text { patients with temporo mandibular } \\
\text { joint }\end{array}$ & Kucuk et al. [69] \\
\hline 55 & GaAlAs & 808 & 500 & 5 & 1.8 & $\mathrm{CW}$ & $\begin{array}{l}\text { Bisphosphonate Related } \\
\text { Osteonecrosis of Jaws }\end{array}$ & Altay et al. [70] \\
\hline 56 & AsGaInP & 660 & $\begin{array}{l}50 \\
100\end{array}$ & $\begin{array}{l}12.5 \\
25\end{array}$ & $\begin{array}{l}1.25 \\
2.5\end{array}$ & $\mathrm{CW}$ & Third-Degree Burns & Brassolatti et al. [71] \\
\hline
\end{tabular}

Table 2: Parameters involved in Low Level Laser Therapy (LLLT).

\begin{tabular}{|c|c|c|c|}
\hline $\begin{array}{l}\text { Irradiation } \\
\text { Parameters }\end{array}$ & $\begin{array}{l}\text { Unit of } \\
\text { measurement }\end{array}$ & & Definitions \\
\hline Wavelength & $\mathrm{nm}$ & $390-10,600$ & $\begin{array}{l}\text { An electromagnetic radiation travels in discrete packets } \\
\text { that also have a wave-like property. }\end{array}$ \\
\hline Power & $\mathrm{W}$ & $10^{-3}-10^{-1}$ & $\begin{array}{l}\text { It is the amount of energy consumed per unit time, and } \\
\text { can be calculated as: } \\
\text { Power }(\mathrm{P})=\text { Energy }(\mathrm{J}) / \text { Time }(\mathrm{sec})\end{array}$ \\
\hline Power density & $\mathrm{W} / \mathrm{cm}^{2}$ & $10^{-1}-10^{0}$ & $\begin{array}{l}\text { Often called Irradiance, or Intensity, is the power } \\
\text { transmitted per unit area, and calculated as: } \\
\text { Power density = Power (W) / Area }\left(\mathrm{cm}^{2}\right)\end{array}$ \\
\hline Energy density & $\mathrm{J} / \mathrm{cm}^{2}$ & $10^{-2}-10^{2}$ & $\begin{array}{l}\text { Energy density is the common expression of LLLT dose } \\
\text { The dose is the most important parameter in laser } \\
\text { Phototherapy, and is usually calculated as } \\
\text { Power / Beam Area } x \text { Time }=\mathrm{J} / \mathrm{cm}^{2} \text {. }\end{array}$ \\
\hline Total irradiation time & $\mathrm{sec}$ & $10-3,000$ & $\begin{array}{l}\text { Is the allowed interval through which the energy has } \\
\text { delivered to the target system. }\end{array}$ \\
\hline
\end{tabular}


Table 3. Review of published studies evaluating the effect of LLLT on different cell lines.

\begin{tabular}{|c|c|c|c|c|c|c|}
\hline No & $\begin{array}{l}\text { Cell Types } \\
\text { Used }\end{array}$ & How the cells are grown & Type of LLLT & Quality of Laser Used & Biological Effects Determination & References \\
\hline 1. & $\begin{array}{l}\text { Human skin } \\
\text { fibroblast cells }\end{array}$ & $\begin{array}{l}\text { Cultures in minimum } \\
\text { essential medium with Earl's } \\
\text { balanced salt solution \& } \\
\text { incubated in } 37{ }^{\circ} \mathrm{C} \text { in } 5 \% \text { \& } \\
85 \% \text { humidity }\end{array}$ & He-Ne Laser & $\begin{array}{l}\lambda: 632.8 \mathrm{~nm} \\
\text { Energy density (ED) } \\
5 \mathrm{~J} / \mathrm{cm}^{2}\end{array}$ & $\begin{array}{l}\text { 1) Non irradiated Hydroxyuria (HU) treated cells had a reduced } \\
\text { number of cells in the central scratch compared to non-irradiated } \\
\text { non treated cells, suggesting that HU inhibited cellular } \\
\text { proliferation. } \\
\text { 2) Irradiated HU treated cells showed an increased number of cells } \\
\text { in the central scratch compared to non-irradiated treated cells. This } \\
\text { increase was due to the stimulatory effect of irradiation with } 5 \\
\mathrm{~J} / \mathrm{cm} 2 \text {. The addition of HU had no significant effect on cell } \\
\text { viability. } \\
\text { 3) The Trypan blue exclusion test showed no significant difference } \\
\text { in percent viability between treated and non-treated cells. } \\
\text { 4) Irradiated non treated cells showed a significant increase in the } \\
\text { formazan dye, which is as a result of cleavage of XTT by the } \\
\text { mitochondrial succinate dehydrogenase in actively proliferating } \\
\text { cells, compared to non-irradiated non treated cells. } \\
\text { 5) Cell viability, proliferation and DNA integrity assays showed } \\
\text { that irradiated and non-irradiated N cells were not significantly } \\
\text { affected at both } 1 \text { and } 24 \text { h post irradiation. } \\
\text { 6) there was a significant decrease in damage at } 24 \text { h compared to } 1 \\
\text { h incubation due to the activation of DNA repair mechanisms. }\end{array}$ & $\begin{array}{l}\text { Mbene et al. } \\
{[108]}\end{array}$ \\
\hline 2. & $\begin{array}{l}\text { E.Coli AB1157, } \\
\text { BW527, } \\
\text { BW9091 and } \\
\text { BW375 }\end{array}$ & $\begin{array}{l}\text { Cultures in exponential and } \\
\text { stationary growth phase. } E \text {. } \\
\text { coli suspensions }\left(1-2 \times 10^{8}\right. \\
\text { cells } / \mathrm{mL} \text {, in } 0.9 \% \mathrm{NaCl} \\
\text { solution) }\end{array}$ & $\begin{array}{l}\text { Laser HTM } \\
\text { Compact model, } \\
\text { AlGaInP }\end{array}$ & $\begin{array}{l}\text { Power: } 10 \mathrm{~mW} \\
\lambda: 658 \mathrm{~nm}\end{array}$ & $\begin{array}{l}\text { 1) There is no alteration of survival fractions of these E. coli } \\
\text { cultures when exposed to laser. } \\
\text { 2) I was indicate that laser exposure induces filamentation in } \\
\text { exponential E. coli AB1157, BW527, BH20, BW375 and BW9091 } \\
\text { cultures at all emission modes }\end{array}$ & $\begin{array}{l}\text { da Silva et } \\
\text { al. [109] }\end{array}$ \\
\hline
\end{tabular}


Table 3. Continued

\begin{tabular}{|c|c|c|c|c|c|c|}
\hline & & & & & $\begin{array}{l}\text { 3) Laser - induced stimulation of cell replication in E.coli } \\
\text { cultures depends on the culture conditions, determining the } \\
\text { particular metabolic state necessary for the division. }\end{array}$ & \\
\hline 3. & Stem cells & $\begin{array}{l}\text { Does not maintion the culture } \\
\text { procedure }\end{array}$ & $\begin{array}{l}\text { He-Ne Laser } \\
\text { Gallium- } \\
\text { Aluminum- } \\
\text { Arsenide ( Ga- } \\
\text { Al-AS) }\end{array}$ & $\begin{array}{l}\lambda: 632.8 \mathrm{~nm} \\
\lambda: 600 \mathrm{~nm} \\
\text { Energy density: } \\
0.5-4.0 \mathrm{~J} / \mathrm{cm}^{2} \\
\text { Power } \\
1-500 \mathrm{~mW}\end{array}$ & $\begin{array}{l}\text { 1) LLLT can increase enhance the proliferation rate of various cell } \\
\text { lines. } \\
\text { 2) The stimulation of cellular proliferation is dependent on the } \\
\text { doses of laser irradiation, as lower doses increase the cell } \\
\text { proliferation rate and other cellular functions, while higher doses of } \\
\text { LLLT have negative effects. }\end{array}$ & $\begin{array}{l}\text { AlGhamdi } \\
\text { et al. [110] }\end{array}$ \\
\hline 4. & $\begin{array}{l}\text { Mesenchymal } \\
\text { stem cells } \\
\text { (MSCs) \& } \\
\text { Cardiac stem } \\
\text { cells ( CSCs) }\end{array}$ & $\begin{array}{l}\text { Cell cultured at } \\
1.3 \times 10^{6} \mathrm{~cm}^{2} \text { in Dulbecco } \\
\text { Modified Eagle Medium } \\
(\mathrm{DMEM}) \text { supplemented with } \\
10 \% \text { fetal bovine serum } \\
(\mathrm{FBS}), \\
2 \mathrm{~m} \mathrm{~mol} / \mathrm{L} \\
\text { Glutamine, } \\
100 \mathrm{U} / \mathrm{ml} \text { pencillin, } \\
100 \mathrm{U} / \mathrm{ml} \text { stroptomycin } \\
\text { CSC cultured in a class } 2 \text { flow } \\
\text { hood. }\end{array}$ & Diod (Ga-As) & $\begin{array}{l}\lambda 804 \mathrm{~nm} \\
\text { Power density: } 50 \\
\mathrm{~mW} / \mathrm{cm}^{2} \\
\text { Energy density: } \\
1 \& 3 \mathrm{~J} / \mathrm{cm}^{2} \\
\text { Exposure time: } 20 \mathrm{sec} \\
\text { or } 60 \mathrm{sec}\end{array}$ & $\begin{array}{l}\text { 1) CSCs of }\left(1 \mathrm{~J} / \mathrm{cm}^{2}\right) 1 \text { and } 2 \text { weeks post LLLT irradiation } \\
\text { significant increase of sevenfold and twofold respectively in the } \\
\text { number cells compared to control. } \\
\text { 2) Significant increase in the number of cells at the energy density } \\
3 \mathrm{~J} / \mathrm{cm} 2 \text { after } 1 \text { week. } \\
\text { 3) The number of } \mathrm{MSC}_{\mathrm{S}} \text { increased post LLLT of } 50 \mathrm{~mW} / \mathrm{cm}^{2} \text { for } \\
20 \mathrm{sec} \text { and } 60 \mathrm{sec}\end{array}$ & $\begin{array}{l}\text { Tuby et al. } \\
{[111]}\end{array}$ \\
\hline 5. & $\begin{array}{l}\text { Fibroblast of } \\
\text { skin cells, } \\
\text { buccal mucosa }\end{array}$ & & & $\begin{array}{l}\lambda: 540 \mathrm{~nm} \\
\quad 600-900 \mathrm{~nm}\end{array}$ & $\begin{array}{l}\text { 1) Increased proliferation, maturation and locomotion as well as } \\
\text { transformation to myo-fibroblasts. } \\
\text { 2) Reduced production of pro-inflammatory prostagland in E2 }\end{array}$ & $\begin{array}{l}\text { Walsh et al. } \\
\text { [112] }\end{array}$ \\
\hline
\end{tabular}




\begin{tabular}{|c|c|c|c|c|c|c|}
\hline & and gingival & & & $\begin{array}{l}\text { Energy density: } \\
0-56 \mathrm{~J} / \mathrm{cm}^{2}\end{array}$ & $\begin{array}{l}\text { 3) Increased production of basic fibroblasts growth factors. } \\
\text { 4) Increased proliferation at low doses and suppressed at high } \\
\text { doses. }\end{array}$ & \\
\hline & Macrophages & & & & $\begin{array}{l}\text { 1) Increased ability to act as phagocytes, and greater secretion of } \\
\text { basic fibroblasts growth factors. } \\
\text { 2) Macrophages resorb fibrin as part of the demolition phase of } \\
\text { wound healing more quickly with LLLT, because of their enhanced } \\
\text { phagocytic activity during the initial phases of the repair response. }\end{array}$ & \\
\hline & Lymphocytes & & & $\begin{array}{l}\lambda: 660 \mathrm{~nm} \\
820 \\
940 \mathrm{~nm}\end{array}$ & Lymphocytes become activated and proliferate more quickly & \\
\hline & $\begin{array}{l}\text { Endothelium } \\
\text { cells }\end{array}$ & & & 4 & $\begin{array}{l}\text { These cells become more motile and are able to migrate across } \\
\text { wound sites with accelerated closure of defects. } \\
\text { Endothelium forms granulation tissue more quickly. Relaxation of } \\
\text { vascular smooth muscles }\end{array}$ & \\
\hline 6. & $\begin{array}{l}\text { Human } \\
\text { Gingival } \\
\text { Fibroblasts } \\
\text { (Hgf3-Pi } 53 \\
\text { NCBI } \\
\text { code C50) }\end{array}$ & $\begin{array}{l}\text { The cells were cultured in } \\
\text { Dulbecco's Modified } \\
\text { Eagle's Medium (Gibco, } \\
\text { USA) supplemented with } \\
10 \% \text { fetal bovine serum } \\
\text { (FBS). This medium was also } \\
\text { supplemented with } 2 \mathrm{mM} \mathrm{L-} \\
\text { glutamine, } 100 \mathrm{U} / \mathrm{ml} \\
\text { penicillin, and } 100 \mu \mathrm{g} / \mathrm{ml} \\
\text { streptomycin. }\end{array}$ & $\begin{array}{l}(\mathrm{Ga}-\mathrm{Al}-\mathrm{As}) \\
\text { diode laser }\end{array}$ & $\begin{array}{l}\lambda: 810 \mathrm{~nm} \\
\text { Power: } \\
50 \mathrm{~mW} \\
\text { Energy density: } 4 \mathrm{~J} / \mathrm{cm}^{2} \\
\text { Exposure time: } 32 \mathrm{sec}\end{array}$ & $\begin{array}{l}\text { 1) The differences between the case and the control groups were } \\
\text { statistically significant on } 48 \mathrm{hr} \text { and } 72 \mathrm{hr} \text { after irradiation. } \\
\text { 2) The results of this in vitro study revealed that good levels of cell } \\
\text { proliferation could be achieved if enough time has been given to } \\
\text { the cells to show the effect of laser irradiation on cell proliferation } \\
\text { rate. }\end{array}$ & $\begin{array}{l}\text { Frozanfar et } \\
\text { al. [113] }\end{array}$ \\
\hline
\end{tabular}




\begin{tabular}{|c|c|c|c|c|c|c|}
\hline 7. & HeLa cells & $\begin{array}{l}\text { They were grown as } \\
\text { monolayers in scintillation } \\
\text { vials }\end{array}$ & He-Ne laser & $\begin{array}{l}\lambda: 632.8 \mathrm{~nm} \\
\text { Power density: } \\
10 \mathrm{~W} / \mathrm{m}^{2} \\
\text { Exposure time: } 10 \mathrm{sec} \\
\text { Energy density: } 100 \\
\mathrm{~J} / \mathrm{m}^{2}\end{array}$ & $\begin{array}{l}\text { 1) When the cells exposed to laser radiation for } 60 \mathrm{~min} \text { before } \\
\text { exposure to } \gamma \text {-radiation, substantial differences was seen between } \\
\text { the survival curve and the curve representing the survival of } \gamma \text { - } \\
\text { irradiated cells. } \\
\text { 2) Increased the number of cells after stimulation with } \mathrm{He}-\mathrm{Ne} \text { in the } \\
\text { exponential phase of growth than that for the control. }\end{array}$ & $\begin{array}{l}\text { Karu et al. } \\
\text { [114] }\end{array}$ \\
\hline 8. & Yeast, HeLa & & He-Ne laser & $\begin{array}{l}\lambda: 632.8 \mathrm{~nm} \\
\text { Power density: } \\
\mathrm{I} \geq 2 \times 10^{11} \mathrm{~W} / \mathrm{cm}^{2}\end{array}$ & $\begin{array}{l}\text { The activity of some enzymes was determined and shows that the } \\
\text { growth stimulation is accompanied by the respiratory activity } \\
\text { increase with no accumulation of toxic intermediates of oxygen } \\
\text { metabolism and by synthetic processes in cell predominance over } \\
\text { degenerative once. The data indicated that the irradiation causes a } \\
\text { cell metabolism rearrangement, the light playing the role of a } \\
\text { trigger controller of the cell metabolism. }\end{array}$ & $\begin{array}{l}\text { Karu et al. } \\
{[115]}\end{array}$ \\
\hline 9. & $\begin{array}{l}\text { Human B- } \\
\text { lymphoblasts }\end{array}$ & $\begin{array}{l}\text { Human B-lymphoblast cells } \\
\text { (NC 37) were grown in } \\
\text { suspension in } \\
\text { RPMI } 1640 \text { medium (Sigma, } \\
\text { Germany) with } 10 \% \text { fetal calf } \\
\text { serum } \\
\text { at } 37^{\circ} \mathrm{C} \text { in a } 5 \% \mathrm{CO} 2 \\
\text { atmosphere. The cells were } \\
\text { sub-cultured } \\
\text { twice weekly in fresh RPMI }\end{array}$ & He-Ne laser & $\begin{array}{l}\lambda: 632.8 \mathrm{~nm} \\
\text { Power: } \\
10 \mathrm{~W} \\
\text { Diameter of beam: } \\
0.75 \mathrm{~cm} \\
\text { Doses ranging } \\
0.5-2.7 \mathrm{~kJ} / \mathrm{m}^{2}\end{array}$ & $\begin{array}{l}\text { 1) The cell viability measurement shows no significant change of } \\
\text { the cell survival. } \\
\text { 2) He-Ne lasers alone do not result in any DNA damage. }\end{array}$ & $\begin{array}{l}\text { Dube et al. } \\
\text { [116] }\end{array}$ \\
\hline
\end{tabular}




\begin{tabular}{|c|c|c|c|c|c|c|}
\hline & & 1640 medium. & & & & \\
\hline 10. & $\begin{array}{l}\text { Human } \\
\text { alveolar bone } \\
\text { fragments }\end{array}$ & $\begin{array}{l}\text { Cells were cultured in } \alpha \text { - } \\
\text { Minimum Essential Medium } \\
\text { (Gibco), supplemented with } \\
10 \% \text { fetal bovine serum } \\
\text { (Gibco), } 50 \mu \mathrm{g} / \mathrm{mL} \\
\text { gentamicin (Gibco), } 0.3 \\
\mu \mathrm{g} / \mathrm{mL} \text { fungizone (Gibco), 10- } \\
7 \mathrm{M} \text { dexamethasone (Sigma, } \\
\text { St.Louis, MO, USA), } 5 \\
\mu \mathrm{g} / \mathrm{mL} \text { ascorbic acid (Gibco), } \\
\text { and } 7 \mathrm{mM} \beta \text { - } \\
\text { glycerophosphate (Sigma) }\end{array}$ & $\begin{array}{l}\text { GaAlAs diode } \\
\text { laser }\end{array}$ & $\begin{array}{l}\lambda: 780 \mathrm{~nm} \\
\text { Power: } \\
70 \mathrm{~m} \mathrm{~W} \\
\text { Diameter of beam } 0.2 \\
\mathrm{~cm} \\
\text { Energy density: } \\
3 \mathrm{~J} / \mathrm{cm}^{2} \\
\text { Exposure time: } 9 \mathrm{~min}\end{array}$ & $\begin{array}{l}\text { 1)Cell growth was affected by time only in LLLT group } \\
\text { 2)From day } 10 \text { to } 14 \text {, LLLT treated cultured showed an increase of } \\
\text { cell growth }\end{array}$ & $\begin{array}{l}\text { AD Petri et } \\
\text { al. [117] }\end{array}$ \\
\hline 11. & $\begin{array}{l}\text { human gingival } \\
\text { fibroblasts }\end{array}$ & $\begin{array}{l}\text { A cell line of human } \\
\text { gingival fibroblasts named } \\
\text { LMF was grown in DMEM } \\
\text { with either } 5 \% \text { nutritional } \\
\text { deficit or 10\% ( FBS) }\end{array}$ & Diode laser & $\begin{array}{l}\lambda: 670 \mathrm{~nm}, \\
780 \mathrm{~nm}, \\
692 \mathrm{~nm} \\
786 \mathrm{~nm} \\
\text { Energy density } \\
\text { (fluence) } \\
2 \mathrm{~J} / \mathrm{cm}^{2} \\
\text { Exposure time: } 9 \mathrm{~min}\end{array}$ & $\begin{array}{l}\text { 1) The irradiated cell number of cell cultured in } 5 \% \text { nutrition deficit } \\
\text { more than that control cell cultured in idial conditions } \\
\text { 2) In the same fluence, IR laser induced a higher cell proliferation } \\
\text { than visible laser when the output powers are different. } \\
\text { 3) Lasers of equal output power presented the similar effect on cell } \\
\text { growth independently of their wavelength. }\end{array}$ & $\begin{array}{l}\text { Almeida et } \\
\text { al. [118] }\end{array}$ \\
\hline 12. & $\begin{array}{l}\text { Human } \\
\text { Macrophages }\end{array}$ & $\begin{array}{l}\text { The macrophage J774 cell } \\
\text { line was grown in (DMEM) } \\
\text { supplemented with } 10 \%\end{array}$ & Diode laser & Power: $70 \mathrm{~mW}$ & $\begin{array}{l}\text { 1) After } 1 \text { day of culture, activated and } 780 \mathrm{~nm} \text { irradiated } \\
\text { macrophages showed lower mitochondrial activity (MA) than }\end{array}$ & $\begin{array}{l}\text { Souza et al. } \\
{[119]}\end{array}$ \\
\hline
\end{tabular}




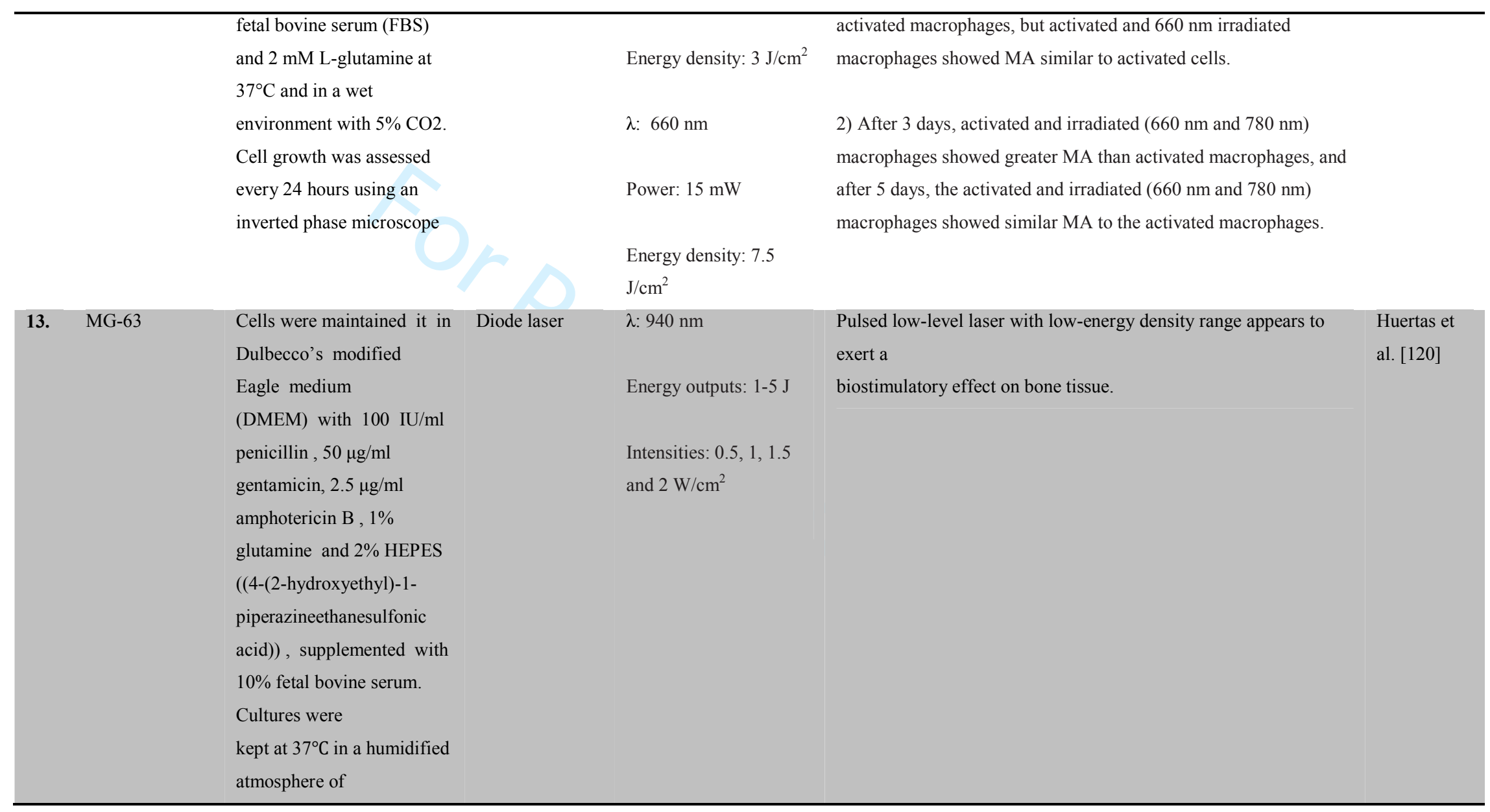


Table 3. Continued

\section{$95 \%$ air and $5 \% \mathrm{CO}_{2}$.}

\begin{tabular}{|c|c|c|c|c|c|c|}
\hline 14. & $\begin{array}{l}\text { Osteoblastic } \\
\text { (MC3T3) cell } \\
\text { line }\end{array}$ & $\begin{array}{l}\text { Cells were grown in sterile } \\
\text { Dulbecco's Modified Eagle's } \\
\text { Medium: Nutrient Mixture F-12 } \\
\text { (DMEM } \\
\text { = F-12) (Invitrogen, } \\
\text { Mount Waverley, Australia) } \\
\text { supplemented with heat-inactivated } \\
\text { fetal bovine serum (FBS) } \\
\text { (Cambrex, East } \\
\text { Rutherford, NJ), and } 200 \mathrm{ml} \\
\text { penicillin } \\
+200 \text { mg =ml } \\
\text { streptomycin (Invitrogen) }\end{array}$ & Diode laser & $\begin{array}{l}\lambda: 830 \mathrm{~nm} \\
\text { Power: } 30 \mathrm{~mW} \\
\text { Energy density: } \\
10 \mathrm{~J} / \mathrm{cm}^{2}\end{array}$ & $\begin{array}{l}\text { Reduction in cell proliferation compared to non-irradiated } \\
\text { controls. }\end{array}$ & Renno et al. [121] \\
\hline 15. & $\begin{array}{l}\text { Human } \\
\text { osteoblast cell } \\
\text { line }\end{array}$ & $\begin{array}{l}\text { Cells were maintained in sterile } \\
\text { medium (Dulbecco's Modified } \\
\text { Eagle's Medium): Nutrient Mixture } \\
\text { F-12 (DMEM= F-12) (Invitrogen, } \\
\text { Mount Waverley, Australia) } \\
\text { supplemented with heat-inactivated } \\
\text { fetal bovine serum (FBS) } \\
\text { (Cambrex, East } \\
\text { Rutherford, NJ), and } 200 \mathrm{ml} \\
\text { penicillin+ } 200 \mathrm{mg}=\mathrm{ml} \\
\text { streptomycin (Invitrogen) }\end{array}$ & $\begin{array}{l}\text { He-Ne laser } \\
632 \mathrm{~nm}\end{array}$ & $\begin{array}{l}\lambda: 632 \mathrm{~nm} \\
\text { Power: } 10 \mathrm{~mW} \\
\text { Energy density: } \\
0.43 \mathrm{~J} / \mathrm{cm}^{2}\end{array}$ & $\begin{array}{l}\text { LLLT promotes proliferation and maturation of human } \\
\text { osteoblasts in vitro, and a significant } 31-58 \% \text { increase in cell } \\
\text { survival }\end{array}$ & Stein et al. [122] \\
\hline
\end{tabular}




\begin{tabular}{|c|c|c|c|c|c|c|}
\hline 16. & $\begin{array}{l}\text { Human monocytic } \\
\text { THP-1 cell line }\end{array}$ & $\begin{array}{l}\text { THP-1cells were grown in } 50 \mathrm{ml} \\
\text { culture flask, the flask containing } \\
20 \mathrm{ml} \text { of medium plus cell, at } 37^{\circ} \mathrm{C} \\
\text { with } 5 \% \mathrm{CO} 2 \text { in a humidified } \\
\text { incubator. }\end{array}$ & $\begin{array}{l}\text { Diode laser } \\
850 \mathrm{~nm}\end{array}$ & $\begin{array}{l}\lambda: 850 \mathrm{~nm} \\
\text { Power: } 9.5 \mathrm{~mW} \\
\text { Energy density: } \\
\left(0.6-27 \mathrm{~J} / \mathrm{cm}^{2}\right) \\
\text { power density of } 29.6 \\
\mathrm{~mW} / \mathrm{cm}^{2}\end{array}$ & $\begin{array}{l}\text { PBM promotes proliferation of human monocyte in vitro, } \\
\text { and a significantly increased cell survival due to increasing } \\
\text { membrane integrity and mitochondrial activity. }\end{array}$ & $\begin{array}{l}\text { Ruwaidah et al. } \\
\text { [123] }\end{array}$ \\
\hline 17. & $\begin{array}{l}\text { stem cells from } \\
\text { exfoliated } \\
\text { deciduous teeth } \\
\text { (SHED) }\end{array}$ & $\begin{array}{l}\text { Cells were maintained in Eagle's } \\
\text { minimum essential medium alpha } \\
\text { modification supplemented with } 10 \% \\
\text { FBS and } 1 \% \text { penicillin and } \\
\text { streptomycin solution (penicillin-- } \\
\text { streptomycin, Gibco, Invitrogen) at } \\
37^{\circ} \mathrm{C} \text { and } 5 \% \mathrm{CO} 2 \text { in incubator. }\end{array}$ & InGaAlP red laser & $\begin{array}{l}\lambda: 660 \mathrm{~nm} \\
\text { Energy density: } \\
\left(1.2-6.2 \mathrm{~J} / \mathrm{cm}^{2}\right)\end{array}$ & $\begin{array}{l}\text { Improved cell viability and proliferation of SHED after laser } \\
\text { irradiation, except for } 1.2 \mathrm{~J} \mathrm{~cm}^{-2} \text {. }\end{array}$ & de Souza[124] \\
\hline
\end{tabular}




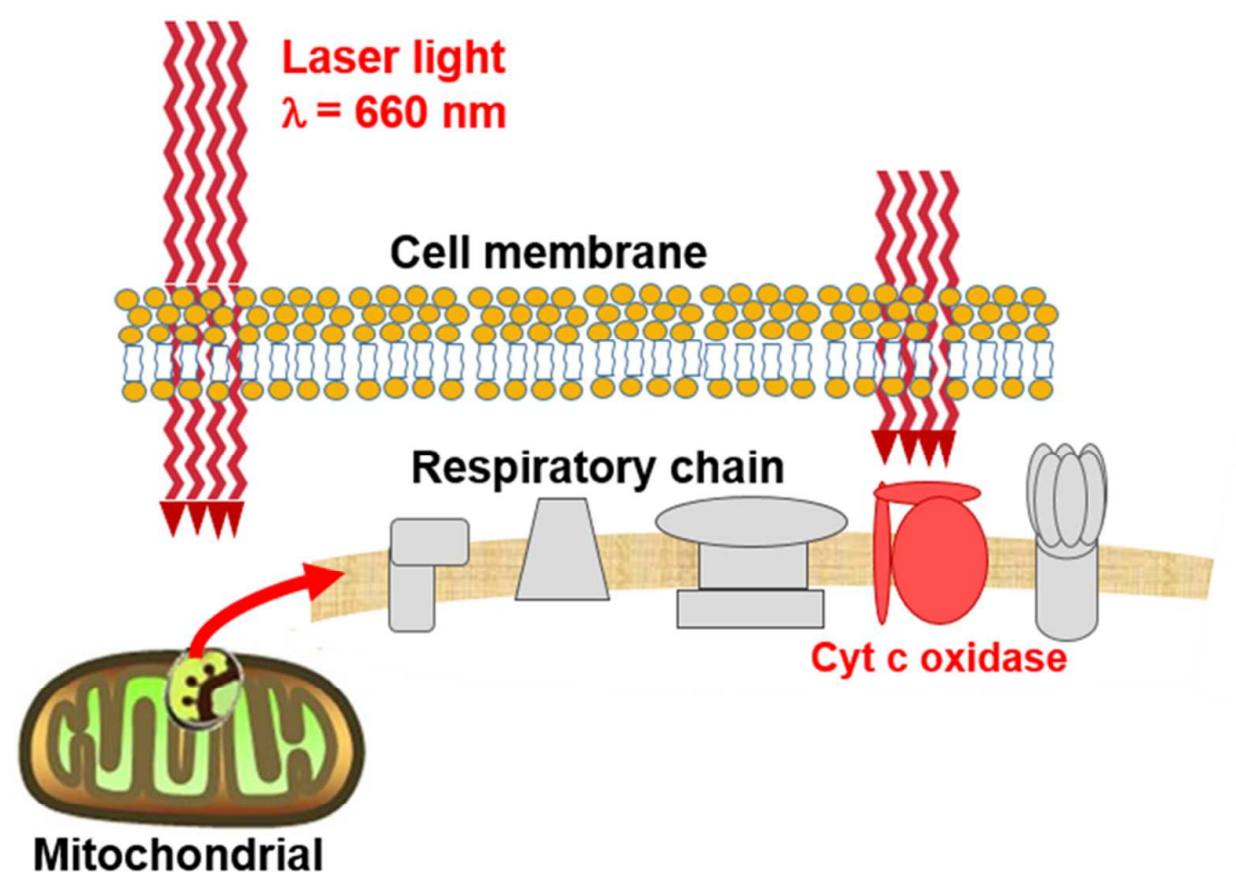

Figure 1. The mitochondrial respiratory chain. (Figure adapted from [148])

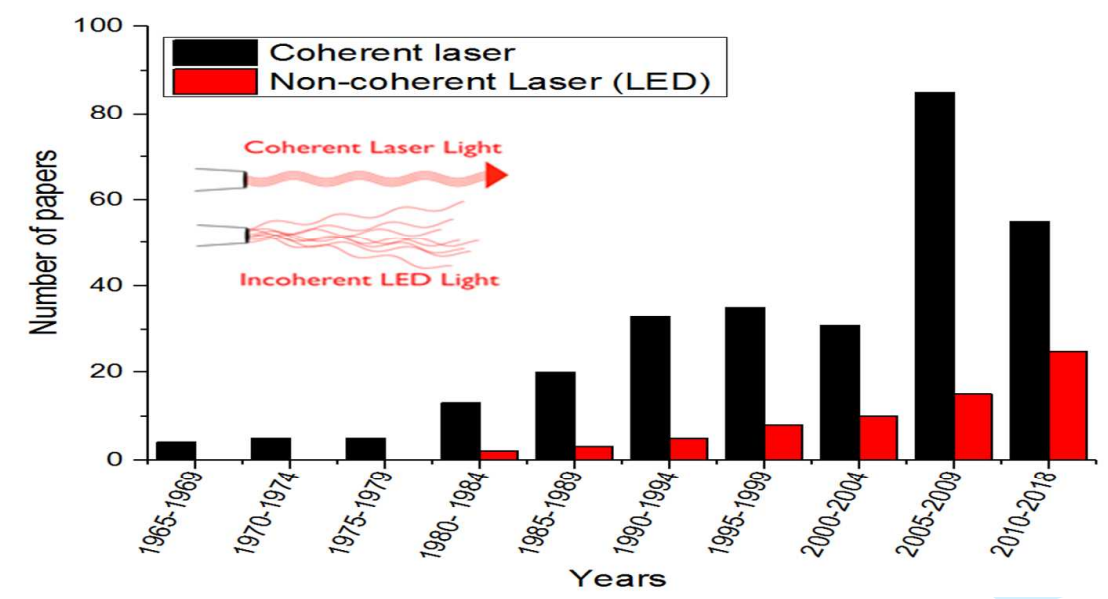

Figure 2. Coherent sources and non-coherent (LED) of LLLT in clinical and laboratory studies on the effect of LLLT on cell and DNA from 1965-2018. 


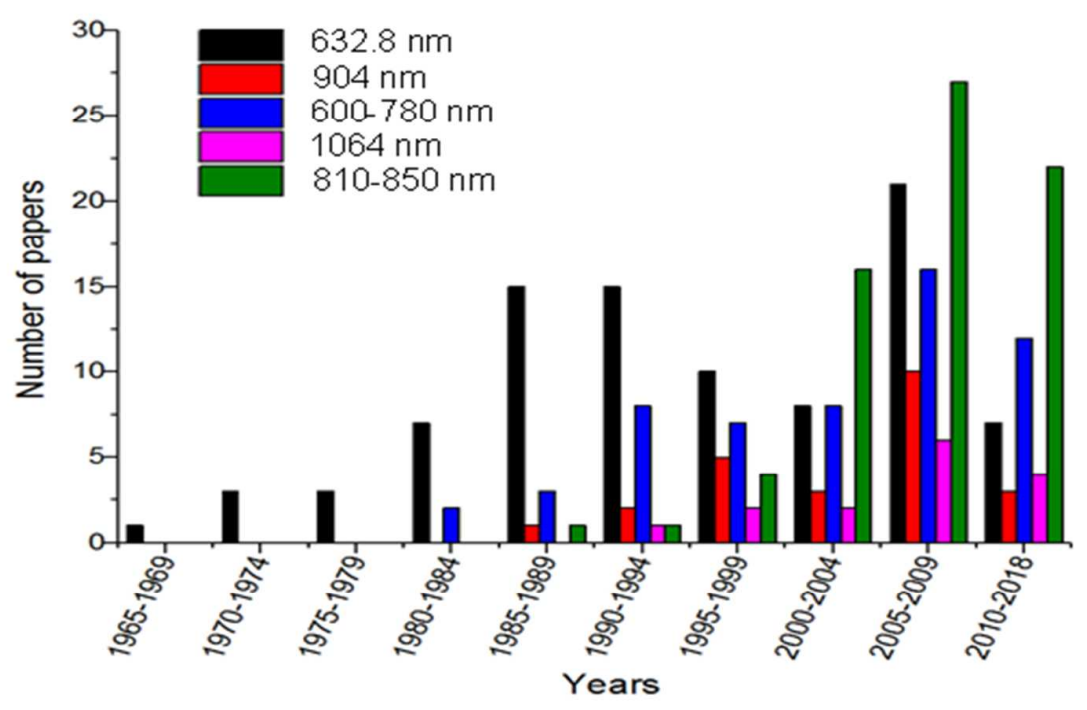

Figure 3. Light sources used in clinical and laboratory studies on the effect of LLLT on cell functions from 1965-2018.

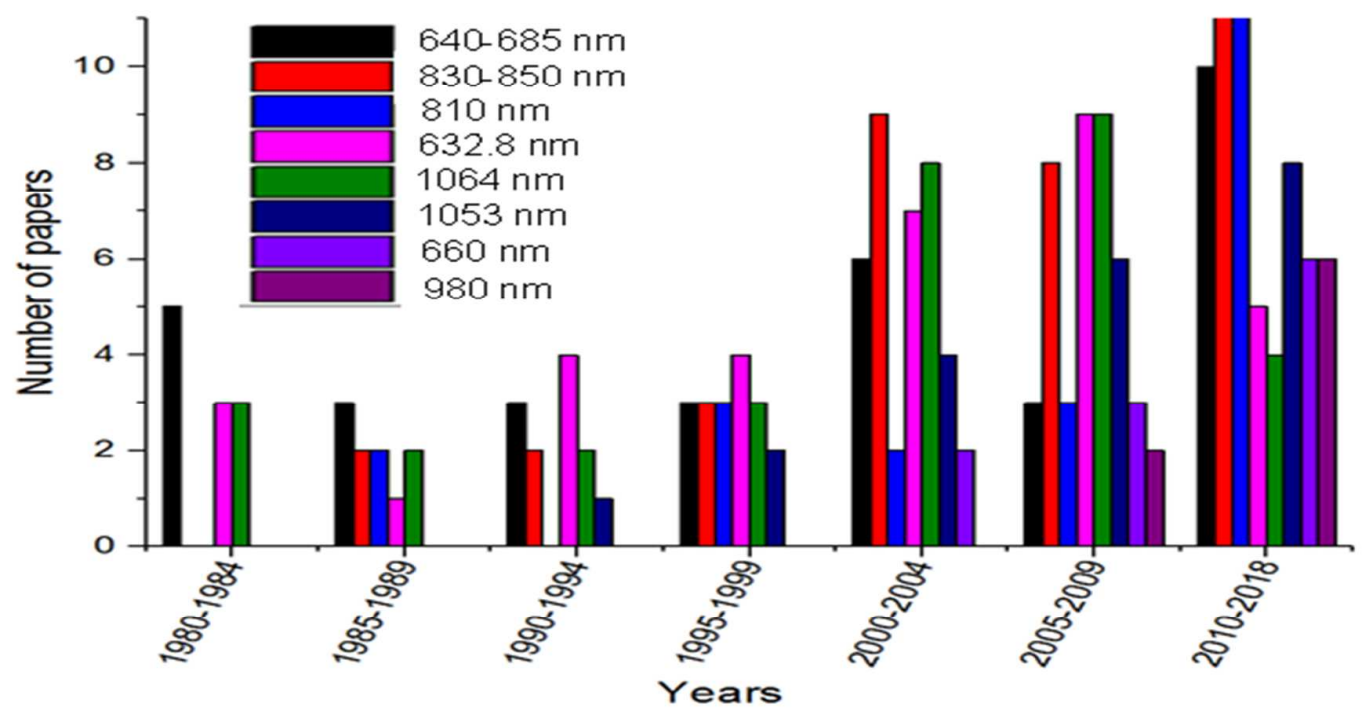

Figure 4. Light sources for LLLT used in clinical and laboratory studies on the effect of LLLT on DNA from 1980-2018. 